\title{
The use of made-up users
}

\author{
Article
}

Accepted Version

Creative Commons: Attribution-Noncommercial-No Derivative Works 4.0

Stenka, R. and Jaworska, S. (2019) The use of made-up users. Accounting, Organizations and Society, 78. 101055. ISSN 0361-3682 doi: https://doi.org/10.1016/j.aos.2019.07.001 Available at https://centaur.reading.ac.uk/83892/

It is advisable to refer to the publisher's version if you intend to cite from the work. See Guidance on citing.

To link to this article DOI: http://dx.doi.org/10.1016/j.aos.2019.07.001

Publisher: Elsevier

All outputs in CentAUR are protected by Intellectual Property Rights law, including copyright law. Copyright and IPR is retained by the creators or other copyright holders. Terms and conditions for use of this material are defined in the End User Agreement.

\section{www.reading.ac.uk/centaur}

\section{CentAUR}

Central Archive at the University of Reading

Reading's research outputs online 
This is a pre-publication version accepted for Accounting, Organizations and Society (in press). Please refer to the published version of this article if you wish to quote from it.

\title{
The use of made-up users
}

"The confinement of the user to a rhetorical representation by others ... is a prevailing feature of the international accounting policy-making arena”. (Hopwood, 1994, p. 249)

\begin{abstract}
While the existence of fictitious users of financial statements has been confirmed in previous research, our study investigates how this powerful yet 'made-up' construct is deployed within the discourses of the main stakeholders as they shape regulatory debates in the international accounting standard-setting arena, including 'real' users themselves. Our study draws on Bourdieu's theorization of dominant discourse as a form of power, and extends it with the phraseological theory of meaning, specifically the linguistic concept of collocation, which focuses on the habitual choices of words in discourse. Using this framework, we conduct a comparative analysis of the recurrent language choices around the term 'user' in comment letters submitted on the selected IASB's regulatory proposals. We provide empirical evidence for the existence of commonalties and subtle differences in the ways in which made-up users are discursively operationalized by the four key accounting constituent groups, the accounting profession, prepares, regulators and 'real' users of financial statements. At the theoretical and methodological level, our study showcases the explanatory power of the concept of collocation to identify and interrogate implicit patterns of dominant discourse as set forth by Bourdieu. We also show that the close investigation of how the dominant discourse of the made-up users works generates a series of new why questions regarding the 'real' users' role in accounting standard setting.
\end{abstract}

Key words: Bourdieu, corpus-based discourse analysis, dominant discourse, regulation, users, IASB

\section{Introduction}

At the heart of accounting regulation is a manifest commitment to serve and protect the interests of users of financial statements (Young, 1994, 2003, 2006; Cooper \& Morgan, 2013). Much is made of the functional nature of accounting reports. Yet, paradoxically, while the needs of users are mobilized as a legitimate basis for regulatory actions, users' involvement in the accounting standard-setting process is limited (Sutton, 1984; Hopwood, 1994; Durocher, Fortin, \& Cote, 2007; Durocher \& Gendron, 2011). The voice of users is almost invariably 
This is a pre-publication version accepted for Accounting, Organizations and Society (in press). Please refer to the published version of this article if you wish to quote from it.

referred to indirectly, often by the representatives of other constituent groups who, with seemingly no or limited input from users themselves, claim to know and articulate the needs, interests, and perspectives of the user community (Young, 2003, 2006; Weetman, Davie, \& Collins, 1996; Harding \& Mckinnon, 1997; Durocher \& Gendron, 2011). In their absence users are "represented rhetorically" (Hopwood, 1994, p. 248), a standardized yet abstract "category to justify and denigrate particular accounting disclosures and practices" (Young, 2006, p. 579).

The extant body of literature suggests that 'users that are used' in the regulatory debates have been constructed, that is, made up over time as "idealized economic actors, mythical individuals who populate the world of positive economics" (Williams \& Ravenscroft, 2015, p. 771). The key players in the regulatory arena construct the needs of users by referring to consistent economic rationality. In a self-referential mode, these needs are then met by the very type of financial information provided by the accounting standards. As Young (2006, p. 596) asserts "the limited conception of the financial statement users allows (necessitates) an equally narrow conception of the purpose of accounting reports" and disregard for the broader moral dimensions of economic life.

While the existence and significance of fictitious users have been confirmed in previous research (Young, 2003, 2006; Williams \& Ravenscroft, 2015), our study investigates in depth how this powerful yet made-up notion is operationalized discursively by the main stakeholder groups that shape regulatory debates in the international accounting standard-setting arena, including 'real' users themselves. We examine a large data set of 2,300 comment letters submitted to the International Accounting Standards Board (IASB) in relation to its controversial regulatory provisions on group accounting and on leases. In contrast to previous research that focused either on the general trajectory of the notion of users in the regulatory arena (Young, 2006; Williams \& Ravenscroft, 2015) or considered this notion in the context of only regulators or one lobby group (Weetman et al., 1996; Young, 2003), our study offers comparative and comprehensive perspectives on the recurrent language choices around the construction and use of made-up users across four main stakeholder groups. In our analysis we consider the accounting profession, preparers, and regulators, as well as the actual users of financial statements. The specific research questions that this paper addresses are:

1) What are the qualities and characteristics that are attributed to made-up users via the specific recurrent language choices in the comment letters by those who advocate users' needs to support their lobbying positions? 
This is a pre-publication version accepted for Accounting, Organizations and Society (in press). Please refer to the published version of this article if you wish to quote from it.

2) Are there any differences or commonalities in those recurrent language choices around made-up users in the comment letters from constituents who we have assigned into four main lobby groups?

The theoretical point of departure for our empirical analysis is Bourdieu's (1987, 1989, 1991, 2000) sociological work on the role of discourse as a form of symbolic domination exercised through habituated use of language. To explore the habituated use of language empirically, we draw on the linguistic insights from Firth's (1957) phraseological theory of meaning, which foregrounds the habitual word choices known as collocations. The study is underpinned by the notion of discourse as a form of social practice that reflects social structures while also playing a key role in their (re)production (Foucault, 1972; Bourdieu, 1991). But discourse is essentially composed of language choices that are its building blocks. It is specifically through recurrent language choices that authorized and widely recognized discourses are constructed and then circulated, forming our understanding of the social world and the practices within (Bourdieu, 1991). The more repeated over time language choices are, the more established and internalized they become forming implicitly dominant discourses (Baker 2006).

In order to empirically identify collocations that point to the patterns of dominant discourse we employ the method of a corpus-based discourse analysis (Stubbs, 2001; Baker, 2006; Pollach, 2012). Studying collocations of made-up users can reveal linguistic choices that are recurrent and conventionally used to construct and operationalize this notion in institutional regulatory discourse, exemplified by the comment letters on regulatory proposals. The corpusbased discourse analysis enables us to compare such recurrent patterns consistently across four main stakeholder groups, shedding light on the differences and similarities in which the notion is constructed by the different epistemic communities of the field. Our study contributes to the relevant research by providing much more nuanced and richer insights into the rhetorical uses of the made-up users not accounted for by previous literature (cf. Young, 2003, 2006), while the methodological approach that we use addresses some of the limitations of the established approaches to discourse adopted in the accounting literature. It strikes a balance between purely quantitative and mixed or purely qualitative methods providing both a bird's eye and street level view and simultaneously combining breadth and depth of the analysis.

Our study responds to Cooper and Robson's (2006) call for more research on multidimensional facets of power (including covert dominance) to demonstrate how social agents argue for and discursively legitimize what they believe to be socially desirable outcomes 
This is a pre-publication version accepted for Accounting, Organizations and Society (in press). Please refer to the published version of this article if you wish to quote from it.

in accounting regulatory debates. Work that seeks to explore in greater depth discursive constructs that are presented as 'truths', and 'truths' that are underwritten by cognitive biases (here the primacy of users' needs), continues to be relevant as such constructs provide for indoctrination and thus for circular, that is, self-replicating legitimation (Roberts, 2009; Young, 2017). In our analysis we focus on the IASB as a significant transnational regulatory institution at the heart of the globalization of financial markets, given the accounting standards it sets are followed, on a mandatory or voluntary basis, in approximately 166 jurisdictions worldwide (www.ifrs.org/use-around-the-world). Our investigation into how the taken-for-granted fictitious construct of users is discursively operationalized in the regulatory arena generates a series of new why questions with regards to the passive role of 'real' users of financial statements in accounting standard setting. It also opens new avenues for research in other domains of accounting where taken-for-granted discursive notions are being 'made-up' and used as justification for the actions of the key agents occupying those domains.

The study proceeds as follows. First, we discuss the implications of the limited presence of 'real' users in the accounting regulatory arena. Then, we take the lead from Bourdieu's theorizing to explore the taken-for-grantedness, that is, hegemony of the made-up user who is constructed and deployed in the absence of the actual users and operates as a dominant discourse in the regulatory arena. Following from that, we outline our novel approach to study patterns of dominant discourses and discuss the results of our empirical analysis. The final section concludes the paper and offers avenues for future research.

\section{The problematization of the absence of 'real' users in the regulatory field}

Research has shown that users of financial statements are the least participating (Weetman et al., 1996; Weetman, 2001; Georgiou, 2010), non-engaging (Young, 2006; Durocher et al., 2007; Georgiou, 2010; Georgiou, 2017), or even 'useless' constituent group and thus fail to provide meaningful input to regulatory outcomes (Durocher \& Gendron, 2011; Pelger \& Spieß, 2017). The limited participation of the user community in the accounting standard-setting process has been explained as: economically motivated because of the perceived (usually low) likelihood of users influencing regulatory outcomes (Sutton, 1984; Tandy \& Wilburn, 1992); due to a tradition of non-responding to regulatory drafts, lack of time, and the perception that participation happens through informal channels (Weetman et al., 1996); or finally the consequence of simple disengagement (Durocher \& Gendron, 2011). Durocher et al. (2007) attempted to link users' perceptions of the characteristics of the standard-setting process to the 
This is a pre-publication version accepted for Accounting, Organizations and Society (in press). Please refer to the published version of this article if you wish to quote from it.

determinants of their participation. For example, the authors reported that cognitive legitimacy granted by users to the accounting profession as the best equipped group to set accounting standards negatively affected users' involvement in the process (Durocher et al., 2007, p. 53). At the same time, Pelger and Spieß (2017), who interviewed IASB board members, found that users were seen by the regulators as "quite a difficult bunch ... not particularly interested in helping ... set standards" taking “financial statements as given” (Pelger \& Spieß, 2017, p. 76). The studies that explored reasons behind limited involvement of actual users in accounting standard setting considered perceptions and opinions expressed by both real users (Durocher et al., 2007; Georgiou, 2010), and those put forward by standard setters (Pelger and Spieß, 2017).

Regardless of the reasons for the actual users' non-participation in the accounting standardsetting process, their absence is problematic as other accounting stakeholders then have the opportunity to assume and potentially (mis)represent users' interests in regulatory debates (Weetman et al., 1996; Young, 2003, 2006) For example, Weetman et al. (1996, p. 75) reported that in the absence of written submissions on regulatory proposals from users "preparers of financial statements are ready to advance their opinions of user needs as justification for an opinion stated”. In their study of IASB processes Durocher and Gendron (2011, p. 255) express concern: "Who benefits from users' exemplary docility? Are standard setters free to modify standards in accordance with their own interests or with the interests of those who exert the most influence?"

Literature exploring accounting regulatory practices revealed that rather than seeking to empirically discover users' needs, standard setters and other stakeholders in the regulatory field have constructed a made-up user instead (Young, 2003, 2006; Williams \& Ravenscroft, 2015; Georgiou, 2017). Young (2006, p. 580) who looked at the historical, economic, and social context of the development of the notion of users in the US setting observed that "the construction of this category has been an ongoing and continuing effort, one that involved standard-setters, committees, academic and many others". The final product is a user who is interested in accounting data, resulting from the application of accounting standards, for making solely economic decisions. Young (2006, p. 594) further argued that "user wants, needs, interests ... are interpreted through the prism of the conceptual framework and its emphasis on rational economic decision makers" (see also, Williams \& Ravenscroft, 2015). This construction has resulted in unification or rather reduction of the multiple and perhaps inconsistent variety of real users and instead focused attention on capital providers, mainly 
This is a pre-publication version accepted for Accounting, Organizations and Society (in press). Please refer to the published version of this article if you wish to quote from it.

investors and their advisers, whose needs have been condensed to the simplicity of rational economic considerations. ${ }^{1}$

This reduction of users to capital market participants is also clearly reflected in the IASB Conceptual Framework (IASB, 2010, 2018) where the objective of general purpose financial reporting is defined as providing information that is "useful to existing and potential investors, lenders and other creditors" (OB2) "to help them assess the prospects for future net cash inflows to an entity" (OB3). This reduction is then developed further as the regulatory madeup user is presumed to be consistently self-interested and rational in her/his economic decisions (Williams \& Ravenscroft, 2015). Such assumption of perfect economic individualism is unrealistic as it disregards the motivational and cognitive unpredictability of human beings (Keys \& Schwartz, 2007). ${ }^{2}$

Consequently, the existing studies demonstrate that the regulatory arena is populated by a made-up standardized perfect homo economicus whose decisions "seemingly occur within a timeless and static economic framework ... assumed to be the same across time periods [and] economic situations" (Young, 2006, p. 596). Users who do not fit this paradigm "could then be easily dismissed as irrational and/or arrogant" (Young, 2006, p. 592) and ignored. Although empirical research has shown that the constructed user bears little resemblance to an actual user in practice (Weetman et al., 1996; Pelger, 2016; Georgiou, 2017), this made-up user has become an unquestionable key reference in shaping accounting standards (Hopwood, 1994, Power, 2010; Williams \& Ravenscroft, 2015). In our next section we will investigate the foundations of legitimizing powers embedded in the discourse of made- up users in the (international) accounting regulatory arena.

\section{Made-up users as a dominant discourse in the regulatory field}

In order to further explore the taken-for-grantedness of the primacy of a constructed user and her/his needs in the regulatory deliberations of the IASB, we turn to the writings of Bourdieu (1987, 1989, 1990, 1991, 2000). Since our study is focused on empirically exploring

\footnotetext{
${ }^{1}$ There are, in fact, many other potential real users of financial statements - for example, employees, regulatory agencies, governments, consumers, and special interest groups - with significantly different (and potentially conflicting) needs (Willmott, 1990; Durocher et al., 2007; Cooper \& Morgan, 2013). Additionally, the nature of users' needs and interests might be specific to time and space (Alexander \& Archer, 2003; Williams \& Ravenscroft, 2015).

${ }^{2}$ Developments in cognitive science and human decision making suggest that the assumption that people are driven by purely economic motives and are consistently rational is not valid (Keys \& Schwartz, 2007). Users (even those who are capital providers) would have labile preferences that are context dependent and would change as one's endowments and level of current wealth change (Williams \& Ravenscroft, 2015, p. 772).
} 
This is a pre-publication version accepted for Accounting, Organizations and Society (in press). Please refer to the published version of this article if you wish to quote from it.

how the made-up notion of users is discursively constructed and operationalized in the regulatory debates to legitimize constituents' positions, Bourdieu's work on language as power (Bourdieu, 1991) offers important theoretical anchors for our analysis.

In Bourdieu's view, the power of language derives from its capacity to perform acts of naming, which in turn produce our "matrix of appreciation and perception" (Bourdieu, 1990, p. 45). He argues that "by structuring the perceptions which social agents have of a social world, the act of naming helps to establish the structure of this world, and does so all the more significantly the more widely it is recognized, i.e. authorized" (Bourdieu, 1991, p. 105). These acts of naming are nothing more than specific linguistic practices and linguistic choices (words and combinations of words) that have been established over time through repeated interactions. What is more, some of the practices and choices become, over time, subject to specific social and historical conditions, generally recognized and accepted, which in turn gives them a dominant status and legitimizing powers. Such dominant linguistic practices become an integral part of both a learned yet deeply internalized set of dispositions shared by social agents that orient their perceptions, that is, habitus and structures of the specific social space (the field that they occupy). In this way, dominant linguistic practices and the norms, beliefs, and associations that they index acquire a tacit grant of faith (Bourdieu, 1987; see also, Gomez \& Bouty, 2011), that is, hegemony. Hegemony dominates not through overt imposition or coercion but through the internalization and reproduction of habituated and thus taken-forgranted ways of reasoning and arguing that are expected and accepted by those occupying the field (Golsorkhi et al., 2009).

Every field is an area of structured, socially patterned activity or practice, in our case disciplinary and professionally defined as an (international) accounting standard setting. It is organized around the body of internal protocols, assumptions, and self-sustaining values that are reflected in and at the same time (re)produced by the dominant language practices that become integral to the field. This provides for the coherence, and to large extent autonomy, of the field (Terdiman, 1987, pp. 806-7; see also; Bourdieu, 1977, 1987, 1998; Malsch, Gendron, \& Grazzini, 2011). Yet, this does not mean that external events or factors are not considered important by agents occupying the field, however, they do need to be translated to the internal logic of the field per dominant linguistic practices that constrain the range of possible legitimate ways to argue and deliberate (Bourdieu, 1987, 1990, 1998; see also, Martin, 2003; Andon, Free, \& Sivabalan, 2014). 
This is a pre-publication version accepted for Accounting, Organizations and Society (in press). Please refer to the published version of this article if you wish to quote from it.

Constructs such as relevance, reliability, comparability, and representational faithfulness but, in particular and more importantly, the overreaching notion of primacy of made-up users' needs, have become legitimate ways to persuade us that particular accounting practices are appropriate and desirable (Young, 2003, 2006). Young showed the trajectory of a made-up user gaining its taken-for-granted status as a "product of historical events, social processes and ideologies" (Young, 2006, p. 578). ${ }^{3}$ Yet, the specific language choices were not the focus of her research. If we want to understand how the concept of made-up users functions as a dominant and thus legitimizing discourse (Bourdieu, 1991), we need to investigate in depth the recurrent language choices, i.e. building blocks that construct this notion. We do it by taking a lead from the linguistics insights on the habitual use of language as discussed in more detail in section 5 of our paper.

The hegemony of a made-up homo economicus as an exemplary user in the regulatory field is significant in structuring of the field. We suggest that no party in the (international) accounting regulatory arena would openly contest the primacy of users' needs in the regulatory field. Even if social agents operationalizing those taken-for-granted, that is, doxic notions can be challenged (there is always much controversy around how a made-up user would benefit from particular accounting solutions), the notions themselves cannot be (Bourdieu, 1987; Golsorkhi et al., 2009; see also, Young, 1996; Pelger, 2016). Such taken-for-grantedness represents both the most subtle and the most powerful system of domination. "If alternatives become unthinkable, challenges become impossible [and] the legitimated entity becomes unassailable by construction" (Suchman, 1995, p. 583). ${ }^{4}$

What is really important for understanding the significance of the made-up users in the standard setting arena is that this taken-for-granted notion allows for the self-referential legitimization of the regulatory actions and outcomes. The focus on the calculative economic needs of users that has been constructed within accounting standard setting almost invariably requires the very information that the standards (or rather standard setters and key players in the field) have identified is of interest to users (Young, 2003, 2006). Arguably, this selfreferentiality is further reproduced by the recently increasing IASB regulatory user outreach

\footnotetext{
${ }^{3}$ Users of financial statements and their needs have not always been a focus when judging 'goodness' of accounting practices. Young (2006) provides a historical overview on how the focus of the objectives of financial reporting in the 1960s and 1970s in the US shifted from a producer/practitioner oriented view (considering what accounting procedures would 'accurately' report economic transactions) to a user-oriented emphasis on decision making with emphasis on why and for who (see also, Williams \& Ravenscroft, 2015).

${ }^{4}$ Pelger (2016) demonstrated the power of the dominant construct of the made-up user (based on narrowly defined decision usefulness) in the IASB debates on the objectives of financial reporting whereby the replacement or compromising of the construct itself "was neither thinkable nor doable" (Pelger, 2016, p. 60).
} 
This is a pre-publication version accepted for Accounting, Organizations and Society (in press). Please refer to the published version of this article if you wish to quote from it.

activities that are supposed to increase integration of the diverse views of users. However, by focusing largely on investors and financial analysts they instead reproduce the dominant

paradigm of a homo economicus. ${ }^{5}$ One could even argue that academic research that empirically investigates users' limited involvement in accounting standard-setting processes (e.g. Weetman et al., 1996; Harding \& Mckinnon, 1997; Georgiou, 2010; Georgiou, 2017) has also contributed to the reproduction of this reduced perceptive on users by focusing only on 'sophisticated' users, mainly financial analysts and institutional investors, as "an established user group of accounting information, and one that is more likely to be familiar with accounting technology than other [user] groups" (Harding \& Mckinnon, 1997, p. 56). Of course, one has to acknowledge issues with the empirical investigation feasibility of other users (whoever they might be) who potentially are not easily 'accessible' or interested in accounting issues.

We now proceed to the discussion of our data and the approach from the linguistics we take to explore empirically how this standardized made-up user is discursively deployed as a dominant language practice in the regulatory institutional discourse.

\section{Comment letters as exemplars of an institutional regulatory discourse}

Although the effects of comment letters on regulatory outcomes cannot be directly measured and are seen by some as questionable (Lagneau-Ymonet \& Quack, 2012; Erb \& Pelger, 2015; Morley, 2016; Pelger, 2016), ${ }^{6}$ we selected comment letters on the IASB regulatory provisions as our data for the following rea. Such written submissions are a key element of the IASB procedural legitimacy (Pelger \& Spieß, 2017, see also, Suchman, 1995), an important component of due process in public consultation, and thus a critical vehicle of interaction and negotiation in the regulatory arena (Mouck, 2004; Richardson \& Eberlein, 2011; Jorissen et al., 2012). Because of their established and conventional genre, comment letters are paramount documents of institutional routines and hence constitute a valuable data

\footnotetext{
${ }^{5}$ For example, Pelger and Spieß (2017) reported how the IASB staff actively used its authority to decide who constituted an 'appropriate' user, eliminating many responses from the user online survey as they were not coming from "members of the investor community" (IASB, 2012, p. 1 in Pelger \& Spieß, 2017, p. 76). The authors also found that this construct of the homo economicus was further supported by other IASB outreach activities, such as webcasts specifically aimed at the Chartered Financial Analysts (CFA) Institute that reinforced the views of the investment management industry as representative of the whole user community.

6 There are no formal rules as to how or even if at all, IASB members (or members of any other accounting standard-setting body) should implement suggestions put forward in the comment letters (Pelger, 2016; Pelger \& Spieß, 2017). Also, Pelger (2016) emphasized the significance of the 'hidden' phases of the regulatory deliberations and the influence of the IASB staff in interpreting comment letters and selecting evidence for discussions (see also, Morley, 2016). Finally, lobbying activities could involve other more indirect and informal forms of influence (Jorissen et al., 2012).
} 
This is a pre-publication version accepted for Accounting, Organizations and Society (in press). Please refer to the published version of this article if you wish to quote from it.

source of institutional regulatory discourse. As such, they are loaded with the "habits, intentions, and rationales held by the agencies by which they have been created" (D'Adderio, 2011, p. 207; see also, Power, 2019). Therefore, they can offer vital insights into the workings of the habitual, that is, established ways to reason and argue, which constitute patterns of the dominant discourse in the regulatory field. In other words, institutional genres such as comment letters on accounting standard proposals do not represent personal idiosyncratic voices; they are written in compliance with explicit and implicit conventions of 'talking and writing' in any given field (Bourdieu, 1987; see also, Baker, 2006).

There is an extensive body of research exploring lobbying via comment letters with a focus on constituent participation (Sutton, 1984; Jorissen et al., 2012), the distribution of power, and impact of lobbying activities (Weetman, 2001; Erb \& Pelger, 2015; Bamber \& McMeeking, 2016; Crawford, 2017), as well as the intensity of the lobbying positions and nature of the arguments provided in the comment letters (Tutticci, Dunstan, \& Holmes, 1994; Weetman et al., 1996; Stenka \& Taylor, 2010; Weetman, 2001; Giner \& Arce, 2012). However, we are not concerned with how impactful comment letters are, whether any particular lobbying group is more successful than others, or whether constituent participation does indeed succeed in maintaining the IASB's legitimacy.

Here, we add to the above literature by focusing solely on the language used in comment letters (lexicon as well as syntax and semantics) to explore deep-seated discursive patterns evidenced by reoccurring language choices associated with the doxic notion of the made-up user. Given that comment letters are formalized manifestations of internalized strategies and practices retained by the text producers, we want to investigate exactly how the fictitious regulatory user is constructed and operationalized as a dominant discourse to see whether 'the use of made-up users' differs among different accounting constituents, including actual users who submitted comment letters.

In order to conduct our comparative analysis we assign the producers of the submissions into four main constituent/lobbying groups that we posit represent the main sources of influence within the international regulatory arena and thus shape regulatory discourse. Those are: (1) the accounting profession, (2) preparers, (3) regulators, and (4) 'real' users themselves. We reflect here a frequently used taxonomy underpinning research into accounting standard setting that is linked to what Booth and Cocks (1990, p. 518) termed "historical blocs and the social relations of production" based on broadly considered commonality of expertise, interests, and modes of rationality. The accounting profession group comprises accounting and 
This is a pre-publication version accepted for Accounting, Organizations and Society (in press). Please refer to the published version of this article if you wish to quote from it.

audit firms, as well as associations of accountants and auditors. The preparers' group covers both corporate and financial preparers, that is, commercial, industrial, service companies, and financial institutions (including insurance companies) together with their associations. The regulatory group comprises national accounting standard setters, stock exchanges and securities commissions, and international regulatory authorities. Finally, the user group refers to investors and financial analysts and their associations as well as consumer organizations, treasuries, and governments (both local and federal). The above constituents are mentioned in the Preface to IFRSs (IASB, 2013, para 17) as the main stakeholders involved in due regulatory process. This taxonomy amalgamates classifications used for example by Giner and Arce (2012), Jorissen et al. (2012), and Pelger and Spieß (2017).

Our particular data sources are comment letters submitted by the constituents in relation to the IASB proposals on (i) group accounting (and related disclosures) and (ii) leases. Each of the proposals addresses issues of off-balance sheet financing. In terms of group accounting, we focus on Exposure Draft (ED) 10 Consolidated Financial Statements (IASB, 2008), which resulted in the release of the two accounting standards IFRS 10 Consolidated Financial Statements (IASB, 2011a) and IFRS 12 Disclosure of Interests in Other Entities (IASB, 2011c). We also consider the Discussion Paper (IASB/FASB, 2008) and the subsequent Exposure Draft (IASB/FASB, 2010a) on Conceptual Framework for Financial Reporting: The Reporting Entity. The former three regulatory documents deal with the parameters of consolidation and disclosures at the standard level, while the latter two address these issues at the conceptual level. In our analysis we also look at the Exposure Draft (ED) 9 Joint Arrangements (IASB, 2007), which was followed by IFRS 11 Joint Arrangements (IASB, 2011b), and which establishes the principles for financial reporting by parties to joint arrangements. In terms of accounting for leases, we consider three regulatory proposals: Discussion Paper DP/2009/1 Leases: Preliminary Views (IASB/FASB, 2009) and two subsequent Exposure Drafts - ED/2010/9 (IASB/FASB, 2010b) and ED/2013/6 Leases (IASB/FASB, 2013). These three regulatory proposals were followed by the release of a new leasing standard IFRS 16 Leases (IASB, 2016) in January 2016. The regulatory documents considered in this paper are presented in Table 1.

Table 1. Regulatory documents on group accounting and on leases

Regulatory Documents

Group Accounting 
This is a pre-publication version accepted for Accounting, Organizations and Society (in press). Please refer to the published version of this article if you wish to quote from it.

Discussion Paper (DP) Conceptual Framework for Financial Reporting: The Reporting Entity. IASB/FASB, 2008

Exposure Draft (ED) Conceptual Framework for Financial Reporting: The Reporting Entity. IASB/FASB, 2010a

Exposure Draft (ED) 10 Consolidated Financial Statements. IASB, 2008

IFRS 10 Consolidated Financial Statements. IASB, 2011a

IFRS 12 Disclosure of Interests in Other Entities. IASB, 2011c

Draft (ED) 9 Joint Arrangements. IASB, 2007

IFRS 11 Joint Arrangements. IASB, 2011b

Leases

Discussion Paper (DP/2009/1) Leases: Preliminary Views. IASB/FASB, 2009

Exposure Draft (ED/2010/9) Leases. IASB/FASB, 2010b

Exposure Draft (ED/2013/6) Leases. IASB/FASB, 2013

IFRS 16 Leases. IASB, 2016

The particular provisions on group accounting and leases have been selected for our study because of their significant implications and highly contentious nature, which, we suggest, would instigate the broad spectrum of discursive patterns in regulatory negotiations. Both group and lease accounting are common financial reporting matters for entities that comply with the IFRS. The group accounting proposals represent a significant change to the process for determining which entities are included in the consolidated statements and, therefore, kept on or off the balance sheet of the group reporting entity in question (Davies, 2011; Nobes, 2014). Leasing arrangements constitute a major and increasing feature of economic activities for large businesses and the proposals provide a new approach to lease accounting, therefore having a significant impact on the value of assets and liabilities included on or off the balance sheet (Cornaggia, Franzen, \& Simin, 2013). Any accounting treatments that implicate offbalance sheet financing due to its significant economic implications have proven to be highly contested, as evidenced by fierce debates on the effects on debt covenants, regulatory capital metrics, compliance costs, employee compensation benchmarks, and IT systems (Stenka \& Taylor, 2010; Davies, 2011).

The comment letters on these specific provisions therefore, we suggest, constitute rich textual sources to show the ways in which the 'made-up users are used' in the regulatory debates generally. It ought to be noted that we seek to provide evidence of the structural patterns of the dominant regulatory discourse that are not accounting issue and thus accounting standard specific. At the same time, of course, the more controversial and more widely relevant 
This is a pre-publication version accepted for Accounting, Organizations and Society (in press). Please refer to the published version of this article if you wish to quote from it.

the issues, the bigger and richer the discursive data because of the volume of interest and variation in opinion and stance (Fairclough, 1989).

In the next section we discuss the approach that we use to investigate recurrent language choices around the notion of made-up users across the main constituents groups that submitted comment letters on those IASB proposals.

\section{The phraseological theory of meaning and a corpus-based approach to discourse}

In order to understand and compare how the doxic notion of a made-up user is discursively constructed and operationalized across the main accounting stakeholder groups, we adopted a linguistic corpus-based approach to discourse, which, to our knowledge, has not yet been fully utilized in accounting research. ${ }^{7}$ We apply this computer assisted set of methods because they allow us to identify recurrent language patterns, that is, collocations in a large amount of naturally-occurring textual data, that is, a corpus. ${ }^{8}$

The concept of collocation goes back to the phraseological theory of meaning and work of one of the most prominent linguists John Rupert Firth (1890-1960) who introduced this concept to modern linguistics. Firth (1957) defined collocations as the habitual and recurrent juxtaposition of words with particular other words that have consequences for meanings. The concept of collocation is based on the fact that meanings arise from the typical combinations of the word with other words in context of use (Stubbs, 2001). How a word combines with other words can give it distinctive meanings, sometimes changing its basic definition altogether. ${ }^{9}$ It is only in recent years that the concept of collocation has been established as an underlying feature of texts through the work of the corpus linguist John Sinclair (1933-2007). Using a large corpus of texts and automated frequency counts, he has demonstrated empirically the pervasiveness of recurrent language choices as opposed to free combinations (Sinclair, 1991). Despite the possibility of combining words to create an infinite number of compilations (Chomsky, 1965), the choices that language users make in actual discourse are much more restricted. It is theoretically possible to us to say or write whatever we want but what we

\footnotetext{
${ }^{7}$ We are aware of only one study (Rutherford, 2005) that adopts some tools from corpus-based approach for the analysis of corporate annual report narratives. The analysis, however, is only based on retrieval of word frequencies and involves manual coding of the most frequent words into positive or negative connotations in the context of companies' performance.

${ }^{8}$ Plural: corpora.

${ }^{9}$ A good example is the word 'cosy', the basic and positive meaning of which is that of comfort. As it happens, 'cosy' co-occurs with the phrase 'little relationship' but the phrase 'cosy little relationship' changes its positive meaning into the negative one of cliquey. 'Flamboyant' is another good example, which means confidence and stylishness. Yet, in combination with 'expenses', as in 'flamboyant expenses', it loses its positive associations and acquires the negative meaning of excess.
} 
This is a pre-publication version accepted for Accounting, Organizations and Society (in press). Please refer to the published version of this article if you wish to quote from it.

actually say or write is much more routinized and conventionalized and it is so because of social, cultural, and institutional conventions of what is appropriate or not appropriate in any given context and genre (Stubbs, 2001; see also, Bourdieu, 1991).

The concept of collocation therefore has two important implications for understanding how identities and ideas are constructed, deployed and reinforced via discourse, specifically institutionalized forms of discourse as is the case in our study.

1) We should not focus on single isolated words; in order to understand how words are discursively operationalized (such as, for example, the term 'user'), we need to go beyond single words and study their use in context, specifically, their lexical neighbourhoods and the repeated items within the neighbourhoods, that is, collocations. Furthermore, collocations as combinations of words need to be further contextualized by studying the extracts of texts in which they occur. Here, close readings and analysis of abstracts of texts (as used in qualitative interpretative accounting research) is indispensable.

2) Collocations understood as recurrent word combinations are not just a matter of individual preferences but reflect established discursive practices of the epistemic community (e.g., accounting profession, preparers, regulators or 'real' users) to which the text producers belong (Stubbs, 2001; cf. van Dijk, 1995). Collocations can therefore point to the existence of conventionally used and thus taken-for-granted discursive patterns that enact the implicit logic of the field that the communities occupy (cf. Baker, 2006, see also, Bourdieu, 1991).

Given the above, we see a conceptual similarity between the concept of collocation and Bourdieu's $(1990,1991)$ theorizing of the reproduction of dominance through habitus, of which (habituated) language use is a part. We therefore posit that through the analysis of recurrent language choices (i.e., collocations as habituated language use) we can empirically identify and explore the discursive patterns through which dominance is exercised. In other words, we can examine how the hegemonic or doxic notion of users is discursively deployed by the key constituent groups in the international accounting standard-setting arena.

The corpus-based approach to discourse used in the present study is based on the principles of the Corpus Linguistics (CL) methodology, which has developed rapidly over the last three decades in the field of linguistics owing to the advances and the availability of linguistic software programmes that allow the exploration of large textual data systematically to "uncover linguistic patterns which can enable us to make sense of the ways that language is used in the 
This is a pre-publication version accepted for Accounting, Organizations and Society (in press). Please refer to the published version of this article if you wish to quote from it.

construction of discourses (or ways of constructing reality)" (Baker, 2006, p. 11). Insights derived from corpus research have increased our understanding of many discourse domains by providing empirical evidence for the existence of language regularities and patterns that could run counter to intuition or not be immediately visible to the 'naked eye' (e.g. Baker, 2006; Jaworska, 2016). This methodological approach has proved vital in studying structural patterns of discourse around socially significant issues such as racism (Krishnamurthy, 1996), homosexuality (e.g. Baker, 2004), climate change (e.g. Grundmann \& Krishnamurthy, 2010; Jaworska, 2018), refugees (e.g. Gabrielatos \& Baker, 2008), and feminism (e.g. Jaworska \& Krishnamurthy, 2012).

The Corpus Linguistics (CL) methodology is based on frequency counts, which are a good point of entry into a corpus, and which are used to identify collocations. Collocation is formally identified in the CL methodology as a strong lexical association between two or more words within a certain span, normally five words to the left and five to the right $(-5$ and +5$)$ at the certain frequency cut-off point (McEnery \& Hardie, 2012). Before proceeding further we will demonstrate how our methodology of a corpus-based discourse analysis, which is novel in accounting research, can contribute to existing approaches to discourse in accounting literature.

Since the 1960s accounting scholars have been paying increased attention to language and discourse (for example, Soper \& Dolphin, 1964; Hines, 1988; Morgan, 1988; Carruthers \& Espeland, 1991; Thompson, 1994). There is now a large body of research investigating a variety of texts produced in the accounting domain and leading to the development and refinement of many theoretical and methodological positions (Beattie, 2014). This also includes an extant literature on discourse in the accounting regulatory arena (Warnock, 1992; Robson, 1994; Masocha \& Weetman, 2007) and on the rhetoric of users in particular (Young, 2003, 2006).

Methodologically, accounting scholars adopt three approaches to discourse: a pure quantitative approach (e.g., Robb, Single, \& Zarzeski et al., 2001; Li, 2008; Cho, Roberts, \& Patten, 2010), a mixed method approach that explores contents performing qualitative analysis with some forms of quantification using tools such as NVivo (e.g., Beattie, McInnes, \& Fearnley, 2004; Brivot \& Gendron, 2011; Baudot, Roberts, \& Wallace, 2017), or a qualitative approach such as Critical Discourse Analysis (CDA) (e.g., Young, 2003; Masocha \& Weetman, 2007; Nielsen \& Madsen, 2007; Duval, Gendron, \& Roux-Dufort, 2015; Stolowy, Gendron, Moll, \& Paugam, 2018; Lupu \& Sandu, 2017). 
This is a pre-publication version accepted for Accounting, Organizations and Society (in press). Please refer to the published version of this article if you wish to quote from it.

The first approach studies large amounts of textual data but conceptualizes language primarily as chunks of information, that is, as a 'bag of words' that can be turned into some form of numerical data (scores, indices) and then correlated with selected non-language variables (e.g., certain performance indicators). This approach is associated with disclosure index studies (e.g., Robb et al., 2001), readability research (e.g., Li, 2008), and more recently with forms of sentiment analysis assisted with computational software programmes (Tetlock, 2007; Cho et al., 2010). Within the quantitative approaches, the notion of readability proved to be particularly popular as an indicator of language complexity, which, in turn, is assumed to be a form of obfuscation or concealment. Readability is mostly measured using the Fog Index, which is based on two components: the number of complex words (words that contain more than two syllables) and the average sentence length. The amount of research on readability of corporate disclosures is vast and most studies, specifically those that are based on a large amount of text (e.g., Li, 2008), show correlations between linguistic complexity measured by the Fog Index and earnings persistence. Yet, the metrics used to identify readability are problematic. This is because they were initially designed and tested on children's literature and it is doubtful whether they are reliable measures to examine 'technical' texts such as disclosure documents (Beattie et al., 2004). From a linguistic point of view, sentence length and the number of syllables are doubtful measures of reading difficulty. Longer sentences can be easier to understand, as they often contain conjugations that make relations clearer, while polysyllabic words are formed using well understood affixes (Bailin \& Grafstein 2001). Moreover, studies that focus solely on readability are rather one-dimensional and capture only one side of language, namely the form (Rutherford 2005), while ignoring the semantics of words. It is, after all, the meanings of words in context that contributes to the formation of views and perceptions.

In a similar vein, studies that turn large amounts of textual data into sentiment or other scores with the help of computational tools (e.g., DICTION) do not take into account the actual workings of language in context (Sydserff \& Weetman, 2002; Tetlock, 2007; Cho et al., 2010). Most of the tools are based on dictionaries that assign one specific meaning to the word independent of its context of usage. As already noted the phraseological theory of meaning (Firth, 1957) has shown that meanings are not stable entities but change in context, specifically when words combine with other words. In addition, tools such as DICTION or other similar text analysers used to assign optimism or positivity scores (e.g., sentiment analysis) do not pay attention to grammatical words and grammatical relations. For example, a sentence such as ' $\mathrm{I}$ 
This is a pre-publication version accepted for Accounting, Organizations and Society (in press). Please refer to the published version of this article if you wish to quote from it.

am not happy, pleased or loved' will be assigned a positive score because of the existence of three positive words as defined by dictionaries, while the key grammatical item 'not', which positions the whole sentence as negative is ignored. Research using this kind of tool therefore offers a rather crude capture of meanings expressed in texts and any claims related to language or discourse based on this kind of study should be treated with caution.

Creating indices of themes or topics is another popular approach in quantitative accounting research concerned with texts (e.g., Robb et al., 2001; Beck et al., 2010; Joseph \& Taplin, 2011). While index studies offer interesting insights into the representations of specific topics in accounting documents, indices are mostly based on categories that are defined a priori and then searched for in texts. The problem with a priori selection is that it might omit topics that are present in the actual data limiting empirical opportunities for the data to 'speak for itself'.

Mixed method approaches, often assisted with tools such as NVivo, have also been extensively adopted by accounting scholars studying texts (e.g., Brivot \& Gendron, 2011; Hazgui \& Gendron, 2015; Baudot et al., 2017). Although computer programmes such as NVivo have been praised for adding more robustness and rigor to manual qualitative analysis of texts (e.g., Smyth, 2008), labelling or coding procedures are not always fully explained and rarely validated. For example, using inter-raters and a measure of inter-raters' agreement such as Cohen's kappa coefficient is a procedure commonly adopted in social sciences, specifically content analysis and linguistics, to ensure better validity of coding procedures (Artstein \& Poesio, 2008; Krippendorff, 2004), but such procedures are rarely utilized in coding accounting documents (e.g. Baudot, 2018).

Parallel to the content-analytical research, a number of accounting scholars have turned to qualitative approaches such as CDA (e.g., Nielsen \& Madsen, 2007; Duval et al., 2015; Stolowy et al., 2018). CDA draws on the Foucauldian notion of discourse as a form of social practice (Foucault, 1972) and pays attention to language choices through which discourses, specifically dominant discourses, become manifest (see also, Fairclough 1989). Although this research offers rich insights into the ways in which organizations discursively construct and operationalize notions such as legitimacy (Lupu and Sandu, 2017), transparency (Nielsen and Madsen, 2007), or fairness (Gendron et al., 2016), in most cases the empirical basis of this research is small, making it difficult to generalize the findings beyond the studied texts and contexts. Also, purely qualitative discourse analysis may be prone to 'cherry picking' of texts and discursive features to prove a preconceived point (Kahneman \& Tversky, 1973, Widdowson, 1998), while "swathes of 'inconvenient' data might be overlooked" (Baker \& 
This is a pre-publication version accepted for Accounting, Organizations and Society (in press). Please refer to the published version of this article if you wish to quote from it.

McEnery, 2015, p. 5) (i.e., confirmation bias). Also, methodology based solely on reading the text is prone to the primacy effect as people in general tend to focus more on information they encounter at the beginning of an activity (Baker, 2006, p. 11). ${ }^{10}$

No method is perfect, and each approach comes with its strengths and limitations. However, the approach used in our study strikes the balance between purely quantitative and mixed or purely qualitative methods providing a both bird's eye and street level view combining simultaneously breadth and depth of analysis. In doing so, it can help reduce some of the limitations of the established approaches to discourse adopted in the accounting literature so far. Here we summarize the main benefits that a corpus-assisted discourse analysis informed by the phraseological theory of meaning (Firth, 1957) can offer for studying discourse in accounting:

1) in contrast to purely qualitative methods, the corpus-based approach is based on larger amounts of language data, making results more generalizable; lexical choices are explored consistently and systematically in large corpora of texts, which provides more reliable findings in terms of recurrent discursive patterns;

2) the use of a software programme reduces the confirmation bias and primacy effects (Kahneman \& Tversky, 1973; Mynatt, Doherty, \& Tweney, 1977; Vallone, Ross, \& Lepper, 1985) that might be present in purely or mixed qualitative methods that rely solely or partially on a manual analysis (Baker, 2006; Pollach, 2012);

3) the corpus-based approach reduces the impact of preconceived assumptions because it lets the data speak first and provides outputs that were not expected or only partially expected thus allowing for serendipitous effects;

4) similar to purely quantitative approaches, the corpus-based method starts with quantifications (frequencies and collocations) and utilizes a software programme ensuring that the procedures are replicable - a researcher using the same corpus of texts and the same procedures will generate the same outputs; yet, in contrast to purely quantitative approaches the corpus-based approach does not turn the language data into scores or indices but explores meanings of words in context based on linguistic insights derived from the phraseological theory of meaning (Firth, 1957);

\footnotetext{
${ }^{10}$ These human biases are not necessarily associated with any particular personal or professional circumstances of a researcher but simply a result of the way human beings process information in general.
} 
This is a pre-publication version accepted for Accounting, Organizations and Society (in press). Please refer to the published version of this article if you wish to quote from it.

5) the corpus-based approach utilizes quantifications (frequencies and collocations), which can usefully guard against over- or under-interpretation of results;

6) using a corpus-based approach does not stop a researcher from exploring selected texts from the corpus in more depth; it gives us the opportunity to explore large amounts of textual data simultaneously from a bird's eye and street level view so that using this approach and its quantitative tools, we can identify recurrent and salient patterns and see how consistently they are used across data sets; then, we can explore them in more depth reading the texts and using interpretive qualitative techniques to uncover the existence of more nuanced discursive strategies (Baker et al., 2008).

In order to address our research questions and explore what qualities and characteristics are attributed to the made-up users across four main constituent groups we have utilized the following procedures.

First, frequencies of the term 'user' in the comments letters produced by the four lobby groups were retrieved to demonstrate and compare the ranking of the term 'user' across all four data sets. This allowed us to position the term in the corpora and to assess comparatively the importance attached to the term. To complement the analysis, we also retrieved frequencies of all potential types of users mentioned in the IASB Conceptual Framework and IFRS Preface as well as referred to in the relevant academic literature (Willmott, 1990; Cooper \& Morgan, 2013). This enabled us to identify the extent to which specific representations of users are featured on the pages of comment letters and what kind of social or epistemic domains they represent. We have also explored the strong noun collocations in proximity of the term 'user' that can point to identities that are habitually associated with the made-up users across the four lobby groups.

Second, in order to explore the characteristics that are systematically and routinely attributed to made-up users, we retrieved and compared the strong descriptor (i.e., modifier) and verb collocations of the term 'user' across the four data sets. This enabled us to reveal established language associations that are persistently linked with fictitious users, reflecting potential differences and commonalities in the discursive construction of this made-up category among the four lobby groups. Descriptor (i.e., modifier) collocations highlight attributes or characteristics persistently assigned to the made-up users, while verb collocations highlight actions and aspects of grammatical transitivity, which in turn can show the level of agency that users are attributed to. 
This is a pre-publication version accepted for Accounting, Organizations and Society (in press). Please refer to the published version of this article if you wish to quote from it.

Transitivity explains the relationships between participants and their roles in actions and processes described in textual data (Richardson, 2007). When studying transitivity, we can identify who does what to whom and as such "transitivity forms the very heart of representation" (Richardson, 2007, p. 54). If a social actor - in our case a made-up user - is portrayed as performing the action described by the verb, then she or he is referred to as an 'agent' and assumes the agency and corresponding responsibility for her or his action. In English, the agent is normally the sentence subject, as in the user demands a change, but in a passive sentence may be expressed in a prepositional phrase proceeded with by, as in a change is demanded by the user. If the user is portrayed as having actions performed to or for her/him, the social actor is at the receiving end of the action with agency and the corresponding responsibility diminished or removed. In linguistics, this is referred to as the 'patient' role. In English, the 'patient' position usually occurs in the object of the sentences, as in the information assists/helps the user. The emphasis on who performs the action described by the verb is important as it indicates the active, when in the 'agent', versus passive, when in the 'patient' position, designation of a social actor (here 'user'). Transitivity is, therefore, a key indicator of our perceptions of actors and actions we describe in the text, the perceptions we might not even be fully aware of. As research in cognitive sciences has shown, the kind of information included in the subject/agent position is always given more priority and importance than the information contained in the object/patient position (Verfaillie \& Daems, 1996; Cohn et al., 2017).

In conducting our analysis we used the Corpus Linguistic software programme Sketch Engine (Kilgarriff, Rychlý, Smrz, \& Tugwell, 2004) and the tools that the programme makes available; frequencies of words were retrieved using Simple Query, whereas Word Sketch was used for collocational analysis. Word Sketch retrieves collocations and groups them in accordance with their grammatical position in relation to the search terms (in our case 'user'). It automatically identifies modifiers as well as verb and noun collocations that are used with the search term depending on its syntactical position in the sentence. Various statistical tests are used to retrieve collocations. Log Dice, which we utilize in our study, is the most suitable metric for identifying and comparing collocations across corpora as it does not (in contrast to other commonly used statistics such as Mutual Information or T-score) depend on the total size of the corpus. This allows the researcher to have a consistent comparison measure across data sets of unequal sizes, as is the case in the present study. Log Dice has a theoretical maximum of 14 but the range of 7 and above indicates a strong association (Rychlý, 2008). We enrich 
This is a pre-publication version accepted for Accounting, Organizations and Society (in press). Please refer to the published version of this article if you wish to quote from it.

our quantitative analysis by qualitative deeper investigation of the specific illustrative examples of the discursive constructs to contextualize our statistical findings.

We will now proceed to our empirical analysis of the comment letters to explore the qualities and characteristics attributed to the made-up users across the four constituent groups, including 'real' users themselves.

\section{Let's meet the made-up users!}

Overall, 2,300 responses have been submitted on the IASB proposals on group accounting and leases that we investigate. Table 2 presents the distribution of responses among the constituent groups - the substantial majority of 1,627 came from preparers, followed by the 358 accounting profession submissions, and 159 and 156 comment letters submitted by regulators and users respectively. The user group in our data sample is the smallest numerically, albeit by a marginal amount from the regulators. This is consistent with the extant research (e.g., Sutton, 1984; Weetman et al., 1996; Young, 2006; Durocher et al., 2007) and confirms the limited input from users in the regulatory processes (who vastly outnumber regulators) in the real world. At the same time our research data confirms that preparers comment most frequently on accounting regulatory proposals (Sutton, 1984; Tutticci et al., 1994; Weetman et al., 1996).

Table 2. Comment letters on the IASB regulatory proposals on group accounting and on leases

\begin{tabular}{cccccc}
\hline Group & $\begin{array}{c}\text { Accounting } \\
\text { Profession }\end{array}$ & Preparers & Regulators & Users & Total \\
\hline $\begin{array}{l}\text { Comment } \\
\text { Letters }\end{array}$ & 358 & 1,627 & 159 & 156 & $\mathbf{2 , 3 0 0}$ \\
\hline
\end{tabular}

Table 3 shows the number of times the lemma ${ }^{11}$ 'user' occurs in our four data sets, that is, the responses submitted by the four constituent groups. Because of the different sizes of the corpora, the frequencies were normalized per 100,000 words to provide a more reliable base for comparison. ${ }^{12}$

\footnotetext{
${ }^{11}$ The term 'lemma' is the canonical form or colloquially dictionary form of a word and includes all morphological forms (plural form, 3rd person singular etc.).

${ }^{12}$ The following formula was used for normalizing the frequencies: the raw frequency divided by the size of the corpus and multiplied by the base of normalization, which is 100,000. For example, the lemma 'user' occurs 1,467 times in the accounting profession corpus and the normalized frequency using the formula is 147 $(1,467 / 1,000,174 * 100,000)$.
} 
This is a pre-publication version accepted for Accounting, Organizations and Society (in press). Please refer to the published version of this article if you wish to quote from it.

Table 3. Frequencies of the lemma 'user' across the texts of the comment letters

\begin{tabular}{lcccc}
\hline & Corpus Size $^{\mathbf{1 3}}$ & Rank $^{\mathbf{1 4}}$ & Raw Freq. & Norm. Freq. \\
\hline Accounting & $1,000,174$ & 106 & 1,467 & 147 \\
Profession & $1,845,527$ & 99 & 2,979 & 161 \\
Preparers & 456,046 & 149 & 534 & 117 \\
Regulators & 368,458 & 100 & 550 & 149 \\
Users & & &
\end{tabular}

As can be seen, the term 'user' is extensively utilized by all constituent groups. However, it occurs most frequently in letters from preparers, followed by letters produced by users and the accounting profession. The difference between the four corpora is statistically significant (Log-likelihood value ${ }^{15}=44.23, d f=3, p<0.001$ ), which confirms that preparers utilize the notion of users more frequently than other constituent groups. This might be interpreted as an effective strategy adopted by preparers to distance themselves from potential allegations of self-interest (which arguably they are the most susceptible to) and instead advance users' need as an efficient legitimating strategy (Weetman et al., 1996). As discussed in Section 2 the formal acknowledgment of decision usefulness and focus on users (even if narrowly defined) is emphasized in the IASB Conceptual Framework (IASB, 2010) and we suggest preparers mobilize it as a 'safe' strategy that resonates not only with the general field specific sympathy for users (Hopwood, 1994; Young, 2006) but with the preferences of the IASB clearly and explicitly outlined in its official provisions. Discursive

The significance of the term 'user' in the comment letters' discourse is also confirmed by the rank of the lemma. As Table 3 shows, 'user' is a high frequency term in all four corpora and in the preparers' and users' corpora belongs to the 100 most frequent words. If we assume that the frequency and rank tell us something about the importance attached to the term, then undoubtedly the term 'user' plays a prominent role in letters submitted by all constituent groups. This provides statistical evidence for the significance of the notion of the made-up user in the regulatory field negotiations (Hopwood, 1994), and suggests that it is indeed an integral

\footnotetext{
${ }^{13}$ The corpus size refers to the number of words in each data set.

${ }^{14}$ It needs to be noted that approximately the top 30 words in each corpus are functional/grammatical words that do not have meaning as such as articles, prepositions, conjunctions, auxiliary verbs etc.

15 Research in linguistics adopts the log-likelihood metric (instead of chi-square) to calculate statistical significance because this metric does not assume that data is normally distributed, which makes it suitable for analysis of real-life textual data (Dunning, 1993).
} 
This is a pre-publication version accepted for Accounting, Organizations and Society (in press). Please refer to the published version of this article if you wish to quote from it.

part of the way constituents argue and justify their positions in the regulatory debates (Young, 2006). In other words, it is indeed part of the implicit logic of the field. ${ }^{16}$

To learn more about 'the use of made-up users' across the main lobby groups and understand what qualities and characteristics are attributed to them, what associations they have, and whether they are assigned agency, we examined the differences in collocational patterns surrounding the term 'user' (looking at verbs, descriptors, and nouns) amongst the four constituent groups.

Considering verbs first, Table 4 presents the raw and normalized (per 100,000 words) frequencies of verb collocations of the term 'user', which helps identify grammatical transitivity and therefore, the level of agency granted to users by the constituents.

Table 4. Raw and normalized frequencies of verb collocations across the 4 data sets ${ }^{17}$

\begin{tabular}{lcccccccc}
\hline & \multicolumn{2}{c}{$\begin{array}{c}\text { Accounting } \\
\text { Profession }\end{array}$} & \multicolumn{2}{c}{ Preparers } & \multicolumn{2}{c}{ Regulators } & \multicolumn{2}{c}{ Users } \\
& Raw & Norm. & Raw & Norm. & Raw & Norm. & Raw & Norm. Freq. \\
& Freq. & Freq. & Freq. & Freq. & Freq. & Freq. & Freq. & \\
$\begin{array}{l}\text { 'User' as } \\
\text { object/patient }\end{array}$ & 316 & $\mathbf{3 2}$ & 462 & $\mathbf{2 5}$ & 96 & $\mathbf{2 1}$ & 116 & $\mathbf{3 1}$ \\
$\begin{array}{l}\text { 'User' as } \\
\text { subject/agent }\end{array}$ & 205 & $\mathbf{2 0}$ & 289 & $\mathbf{1 6}$ & 85 & $\mathbf{1 9}$ & 119 & $\mathbf{3 2}$ \\
\hline
\end{tabular}

All lobby groups, with the exception of users, use more verb collocations with the term 'user' when 'user' is the object/patient. The pattern of 'user' as an object is the strongest in the case of the accounting profession, showing that the made-up users in this context are treated as the receivers of actions. This hints at a rather pedagogic stance, based on (self)perception of specialized expertise on the part of the accounting profession (Hines, 1989; Suddaby, Cooper, $\&$ Greenwood, 2007) as opposed to users who “aren't experts in accounting” (Pelger \& Spieß, 2017, p. 76) and may be in need of some 'schooling' in the use of financial statements. In contrast to the other lobby groups, user commentators place the term 'user' most frequently as the subject, that is, in agent position (normalized frequency of 32). Interestingly, however, the difference is not substantial and the user lobby group also refers to the lemma 'user' frequently as the object (the normalized frequency of 31). This shows that the users themselves engage to

\footnotetext{
${ }^{16}$ The question as to whether the constituents genuinely care about users' needs remains open. We would assume that users are the group most likely to genuinely care about their own interests. This, however, is outside the scope of our study.

${ }^{17}$ In order to obtain all instances of verbs occurring in the vicinity of user, the minimum frequency threshold was 1.
} 
This is a pre-publication version accepted for Accounting, Organizations and Society (in press). Please refer to the published version of this article if you wish to quote from it.

a large extent (perhaps unconsciously) with the 'ruling' operationalization of the user discourse, in which the 'user' is a passive actor, discursively represented by others rather than actively participating in the process (Young, 2003, 2006). In other words, real users themselves seem to be taken in and by the regulatory game (Bourdieu, 2000) in the same way as other constituents. Overall, however, it needs be noted that the user group does assign to 'users' slightly more agency and thus responsibility in shaping accounting practice, whereas in the letters of the other three groups, 'users' are consistently more 'objectified'. This becomes even more visible when we examine the types of verb collocations surrounding the term 'user' in object and subject positon.

Table 5 presents examples of the strongest verb collocations of the term 'user' when placed in the object/patient position.

Table 5. The strongest verb collocations of the term 'user' in the object/patient position

\begin{tabular}{lrlrlrlrr}
\hline \multicolumn{2}{c}{$\begin{array}{c}\text { Accounting } \\
\text { Profession }\end{array}$} & \multicolumn{2}{c}{ Preparers } & \multicolumn{2}{c}{ Regulators } & \multicolumn{2}{c}{ Users } \\
\hline \multicolumn{1}{c}{ Verbs } & LogDice & Verbs & LogDice & Verbs & LogDice & Verbs & LogDice \\
\hline enable & 10.79 & provide & 10.71 & enable & 11.24 & help & 11.99 \\
allow & 10.74 & confuse & 10.00 & protect & 10.65 & enable & 11.44 \\
help & 10.59 & enable & 10.26 & assist & 10.49 & allow & 10.29 \\
assist & 10.52 & help & 10.23 & allow & 10.16 & confuse & 10.05 \\
provide & 10.42 & assist & 9.89 & provide & 9.53 & benefit & 10.04 \\
confuse & 8.91 & allow & 9.53 & confuse & 9.32 & permit & 9.61 \\
\hline
\end{tabular}

As can be seen, the actions performed to or for 'users' are predominantly related to the notion of enabling, providing, and helping. This discourse thus portrays the made-up user as 'needy' and easily 'confused', displaying pedagogic undertones. Both the accounting profession and preparers, in particular, use similar discourses as they focus on assistance in relation to users' (implied as limited) understanding, often in an empty rhetorical manner as illustrated below: 
This is a pre-publication version accepted for Accounting, Organizations and Society (in press). Please refer to the published version of this article if you wish to quote from it.

The obligation to pay liabilities should be presented separately on the statement of financial position ... as it will enable users to better understand ${ }^{18}$ the entity's underlying approach to financing its asset base. (AP - $\mathrm{CL} 5^{19}$ )

We welcome the requirement to disclose relevant quantitative and qualitative information as this will provide useful information to users .... and enhance their understanding of the role and impact of lease arrangements on the entity. (AP - CL79)

This type of disclosure may actually confuse the user of the financial statements as the user will not have all of the detailed information required to determine how the gross amounts were calculated. (AP - CL13)

This concept is overly complex, impractical to apply and would likely confuse financial statement user. $(\mathrm{P}-126)$

The use of judgement should be disclosed to help users to understand the financial statements not to challenge them. (P-CL89)

We also appreciate the need to provide additional disclosures to assist users in their understanding of the reporting entity's [risk] exposures. (P - CL115)

Although the verbs 'help' and 'enable' do occur in the remaining groups, some differences can be noticed. For example, regulators seem to reinforce the idea of protection, which is absent from the other groups. This idea is reinforced almost verbatim through the same wording across letters from different regulators as the examples below illustrate:

Appropriate caption and note disclosure should serve to sufficiently protect users from misunderstanding the substance and nature of the information included. (R - CL67)

Appropriate caption and note disclosure should serve to sufficiently protect users with reasonable business knowledge from misunderstanding the substance and nature of the information included. (R - CL8)

In contrast to the three other groups, the user lobby group associates 'users' with 'benefit', presuming receiving some kind of an advantage or improvement, which is not surprising given

\footnotetext{
18 The underlying is added by the authors to highlight the key discursive features and continues throughout the paper.

19 The abbreviations are as follows: AP - Accounting Profession; P - Preparers; R - Regulators; U - Users; and $\mathrm{CL}-$ Comment Letter.
} 
This is a pre-publication version accepted for Accounting, Organizations and Society (in press). Please refer to the published version of this article if you wish to quote from it.

that users are supposed to be legitimate beneficiaries of financial statements. Hence, they cannot be criticised for self-promoting tendencies. They are formally entitled to a self-serving behaviour and self-serving arguments.

This should lead to more consistent application of the consolidation requirements, which would benefit users of financial statements by providing more comparable information. (U-CL3)

Information by legal structure would also provide context for users to evaluate and benefit from the other information provided in financial statements today. (U - CL12)

We turn our attention now to the strongest verb collocations of lemma 'user' when placed in the subject/agent position. As Table 6 shows, the user lobby group utilizes a range of different verb collocations as compared to other lobbying constituencies, including 'want', 'assess', and 'require', implying a more active and assertive position when it comes to madeup users' actions. The verb association of 'want' is the strongest among commenting users and it is absent in the case of other constituent groups.

Table 6. The strongest verb collocations of the term 'user' in the subject/agent position

\begin{tabular}{lrlrlrrrr}
\hline \multicolumn{1}{c}{ Accounting Profession } & \multicolumn{2}{c}{ Preparers } & \multicolumn{2}{c}{ Regulators } & \multicolumn{3}{c}{ Users } \\
\hline \multicolumn{1}{c}{ Verbs } & LogDice & \multicolumn{2}{c}{ Verbs } & LogDice & Verbs & LogDice & Verbs & LogDice \\
\hline understand & 10.07 & understand & 11.31 & advise & 11.00 & want & 10.62 \\
make & 9.31 & need & 10.04 & inform & 10.38 & make & 10.08 \\
adjust & 9.29 & adjust & 9.11 & seek & 10.27 & receive & 9.77 \\
need & 9.12 & make & 8.89 & rely & 9.44 & assess & 9.63 \\
express & 9.05 & desire & 8.68 & support & 9.37 & need & 9.09 \\
rely & 8.83 & find & 8.54 & understand & 9.24 & require & 8.79 \\
\hline
\end{tabular}

The extracts below illustrate this pattern:

Users want to be able to compare previous and current year information based on the same accounting treatment. (U - CL237)

However, we feel that whenever it is possible, parties to a joint arrangement should also disclose the fair market value of their interest in joint arrangements. This would help users assess the degree of risk associated with the venture. (U-CL160) 
This is a pre-publication version accepted for Accounting, Organizations and Society (in press). Please refer to the published version of this article if you wish to quote from it.

From our experience, consolidated financial statements of these types of investment companies would be useless because they would exclude information that would affect decisions users make. (U - CL5)

While we don't disagree with these disclosure requirements ... they are substantially less in scope than what we believe users require to understand the nature of the lessor arrangements. (U-CL 24)

Conversely, the accounting profession and preparers seem to emphasize users' understanding as highlighted by the strongest association with the cognitive verb ${ }^{20}$ 'understand'. However, the context to which 'understand' is used is quite paternalistic. The two lobby groups seem to 'know' what the cognitive (implied as limited) needs of 'users' are and speak on their behalf, which, in turn, implies a somehow more passive role assigned to the constructed users, as the extracts below show:

Adding a decision tree to the proposed language would help users understand how to apply the guidance to their specific situations. (P - CL204)

Requiring these disclosures for all structured entities, irrespective of the extent of the reporting entity's ongoing involvement is likely to over burden users ... and obscure information on the structured entities that users most need to understand. (P - CL313)

Where these options exist, we believe that they must be adequately disclosed so as to ensure users understand the uncertainty and timing of the associated cash flows. (AP CL80)

AC concurs with the Board's proposals in respect of disclosures of qualitative and quantitative information that enables the user of financial statements to understand the impact of accounting for leases in the financial statements by lessees and lessors. (AP CL-77)

Looking at the verb collocations with the term 'users' in the subject position in comment letters produced by regulators, the strongest association is with 'advise'. The regulators portray themselves as being advised by and therefore more engaged with 'users' (whose identity is never elaborated on further) and thus entitled to speak on their behalf. This language use creates

\footnotetext{
${ }^{20}$ Cognitive verbs describe mental operations or processes of knowledge creation, processing, or dissemination. Typical cognitive verbs are: think, understand, define, evaluate, etc. (Biber et al., 1999).
} 
This is a pre-publication version accepted for Accounting, Organizations and Society (in press). Please refer to the published version of this article if you wish to quote from it.

an image of trust and somehow more intimate relationship between (made-up) users and standard setters as illustrated in the examples below:

These users advise us that they would prefer to have sufficient disclosure of the terms of such contingent rents and historical information to enable them to make their own estimates. ( $\mathrm{R}$ - CL7)

In fact, users have advised us that they would prefer to have sufficient disclosure of the terms of these contingent payments in order for them to make their own estimates. $(\mathrm{R}-$ CL11)

Again, we noticed the verbatim phrasing, which suggests a highly conventionalized repetitive 'use of the made-up users'. Those made-up users are consistently portrayed as actively advising the regulators about their preferences that are never however discussed in any detail. This is in line with the image of the regulatory bodies as concerned unbiased listeners that take actions in response to their constituencies, that is, users of financial statements requests to 'fix' flawed accounting (cf. Young, 1994). This is very much consistent with the notion of 'protection' offered by regulators when fictitious users are referred to in an object/patient position as already discussed and presented in Table 5.

Turning our attention to descriptor collocations, we can observe an interesting pattern of the frequent association of the term 'user' with Vague Quantifying Expressions (VQE) as gleaned from the strongest modifiers of invoked users. Table 7 provides the types of VQE used by the four lobby groups together with their LogDice scores.

Table 7. Types of Vague Quantifying Expressions (VQE) as collocations of 'users'

\begin{tabular}{|c|c|c|c|c|c|c|c|}
\hline \multicolumn{2}{|c|}{ Accounting Profession } & \multicolumn{2}{|c|}{ Preparers } & \multicolumn{2}{|c|}{ Regulators } & \multicolumn{2}{|c|}{ Users } \\
\hline$V Q E$ & LogDice & $V Q E$ & LogDice & $V Q E$ & LogDice & $V Q E$ & LogDice \\
\hline range & 8.739 & more & 8.961 & range & 9.463 & other & 9.548 \\
\hline more & 8.715 & other & 8.422 & more & 9.153 & some & 8.971 \\
\hline many & 8.515 & most & 8.173 & some & 8.114 & many & 8.322 \\
\hline some & 8.259 & many & 7.535 & many & 8.52 & & \\
\hline number & 7.922 & range & 7.354 & & & & \\
\hline
\end{tabular}


This is a pre-publication version accepted for Accounting, Organizations and Society (in press). Please refer to the published version of this article if you wish to quote from it.

As can be seen, all constituent groups use the same or similar types of VQEs when referring to the term 'user'. For example, in the letters from the accounting profession we find five types of VQEs, of which 'range', 'more', and 'many' are the strongest associations. A similar pattern can be observed in the preparers' and regulators' letters with real users offering slightly fewer VQEs. Interrogating the data, we noticed that the quantifiers are often accompanied by other modifiers of vagueness. The extracts below exemplify this pattern, in that the collocation 'user' + 'range' is preceded by the vague descriptor 'wide' or 'broad'. However, this has only been observed in comment letters from the accounting profession, preparers, and regulators.

We agree that financial reports are of interest to a wide range of users that is not restricted to providers of capital, but we do not agree that financial reports are of equal importance to all interested parties. (AP - CL350)

The use of this definition could mean that certain of these structures may not meet the definition of a reporting entity, despite being an area of interest to $\underline{a}$ wide range of users. (AP - CL247)

We are not convinced this increase in costs will also increase the benefits for a broad range of users. ( $\mathrm{R}-\mathrm{CL} 77)$

For example, the entity view provides information that is not composed for one specific group of users of financial reports but refers to the needs of a broader range of users. $(\mathrm{P}$ - CL12)

Although a variety of 'users' is implied, we cannot identify who these invoked users are, as no explanation is provided and no examples are given. It appears that the notion 'user' is treated as a standardized and homogenic unspecified category, paradoxically through references to heterogeneity, for example, 'wide' or 'broad range'. This pattern seems to be less prominent in the real users' corpus, in which we find only three types of VQEs. However, overall they do use VQEs, suggesting that actual users (to a lesser extent) have also internalized this practical universalization, that is, generalization in practice (Bourdieu, 1987), which seems to be the 'ruling' interpretation of the made-up user as a general category of legitimation. These findings confirm the claims in the relevant literature of the user as an abstract regulatory rhetorical device rather than an actual, that is, flesh and blood user of financial statements (Hopwood, 1994; Young, 2003, 2006)

Although the most frequent modifiers of 'users' point to homogenizing representations, we were also interested to find out exactly what kind of identities (if any) appear in the vicinity of the term 'user' across all constituent groups. Since identity can be expressed through the 
This is a pre-publication version accepted for Accounting, Organizations and Society (in press). Please refer to the published version of this article if you wish to quote from it.

grammatical category of nouns, we therefore look at the most frequent noun collocations with the term 'user' to see precisely what types of representation (of social or epistemic domains) are associated with the term. This can reveal the identity commonly attached to the made-up users.

Table 8. The strongest noun collocations of the term 'user'

\begin{tabular}{lrlrlrlr}
\hline Accounting & LogDice & Preparers & LogDice & Regulators & LogDice & Users & LogDice \\
\hline statement & 11.944 & statement & 12.28 & statement & 11.531 & statement & 11.674 \\
information & 11.434 & financial & 12.02 & information & 11.436 & information & 10.969 \\
group & 9.056 & information & 11.68 & company & 9.178 & council & 9.844 \\
disclosure & 9.036 & investors & 8.743 & range & 9.142 & investors & 9.671 \\
company & 8.533 & disclosure & 8.705 & comparability & 9.015 & decision & 9.54 \\
range & 8.177 & confusion & 8.244 & group & 8.993 & purpose & 9.121 \\
nature & 7.955 & analysts & 8.208 & disclosure & 8.963 & disclosure & 9.062 \\
entity & 7.864 & community & 8.078 & investors & 8.59 & group & 8.924 \\
constituency & 7.786 & decision & 7.974 & investment & 8.377 & quality & 8.696 \\
value & 7.716 & result & 7.921 & understanding & 8.337 & requirement & 8.679 \\
number & 7.701 & value & 7.89 & term & 8.32 & uncertainty & 8.489 \\
usefulness & 7.594 & understanding & 7.878 & result & 8.089 & risk & 8.373 \\
interest & 7.496 & group & 7.823 & majority & 7.949 & extent & 8.276 \\
investors & 7.482 & company & 7.817 & interest & 7.938 & value & 8.179 \\
impact & 7.401 & usefulness & 7.776 & complexity & 7.921 & creditors & 8.114 \\
\hline
\end{tabular}

Table 8 shows the 15 strongest noun associations with the term 'user'. As can be seen, we did come across the 'mystical' homo economicus (Williams \& Ravenscroft, 2015) as 'investors' is the only social group appearing on the lists of noun collocations across all four data sets. As suggested in the relevant literature (Young, 2006; Williams \& Ravenscroft, 2015), we found that the identity of users is indeed represented by an economic decision maker, implying that economic rational considerations as determined by markets are a priority and accounting regulatory outcomes serve economic ends. Investors are indeed a focus of the deliberations; remaining users, if mentioned at all, are portrayed as a residual and reduced to generic 'other users' or 'other primary users'. Interestingly, the collocations are particularly strong in the case of the user constituents, which shows that the 'real' users who submit comment letters do indeed seem to identify themselves with investors. Also, it is the user community that associates 'creditors' with invoked users who are individuals equally concerned with rational economic decisions. This is illustrated by the examples below: 
This is a pre-publication version accepted for Accounting, Organizations and Society (in press). Please refer to the published version of this article if you wish to quote from it.

Users such as creditors and investors should be equally cognizant of all obligations regardless of the nature of the underlying asset. (U - CL32)

We urge the Board to expeditiously issue an improved standard so that significant offbalance sheet transactions are made more transparent to investors and other users of financial statements. (U - CL2)

This methodology (fair value) shows better information to users (investors). ( $\mathrm{P}-\mathrm{CL}$ 144)

We believe investors and other users would be better served with information that reflects the total lease obligation or asset without any interest adjustment. ( $\mathrm{R}-\mathrm{CL} 30)$

... an expected outcome measurement for liabilities does not provide useful decisionmaking information for investors or other primary users of the financial statements. (AP - CL112)

The only other representation of users that does not belong to the group of finance providers is 'analysts', who are mentioned in the vicinity of the term 'user' by preparers. However, although analysts are not capital providers as such, they are still rational economic decision makers, who offer recommendations regarding financial investment opportunities to capital providers (current and potential investors).

In order to further explore what representations of users are given prominence on pages of the comment letters across the four constituent groups we examined the frequencies and use of all other potential types of users mentioned in the IASB Conceptual Framework and IFRS Preface and referred to in the relevant academic literature (Willmott, 1990; Cooper \& Morgan, 2013) as examples of those who might use financial statements. This allows us to see exactly what kind of user identities are foregrounded or backgrounded and to verify the significance attached to investors as users compared with other potential user groups. Table 9 shows the frequencies of mentions of these potential representations of users. It confirms that indeed investors are the most frequently mentioned identity assigned to users across all constituent groups with the tendency being the strongest in case of the user lobby group (which is in line with the findings revealed by noun collocations reported in Table 8).

Table 9. Frequencies of specific made-up user identities in the four corpora

\begin{tabular}{cccc}
\hline $\begin{array}{c}\text { Accounting } \\
\text { Profession }\end{array}$ & Preparers & Regulators & Users \\
\hline
\end{tabular}


This is a pre-publication version accepted for Accounting, Organizations and Society (in press). Please refer to the published version of this article if you wish to quote from it.

\begin{tabular}{|c|c|c|c|c|c|c|c|c|}
\hline & $\begin{array}{l}\text { Raw } \\
\text { Freq. }\end{array}$ & $\begin{array}{l}\text { Norm. } \\
\text { Freq. }\end{array}$ & $\begin{array}{l}\text { Raw } \\
\text { Freq. }\end{array}$ & $\begin{array}{l}\text { Norm. } \\
\text { Freq. }\end{array}$ & $\begin{array}{l}\text { Raw } \\
\text { Freq. }\end{array}$ & $\begin{array}{l}\text { Norm. } \\
\text { Freq. }\end{array}$ & $\begin{array}{l}\text { Raw } \\
\text { Freq. }\end{array}$ & Norm. Freq. \\
\hline investor & 548 & 55 & 1,325 & 72 & 146 & 32 & 334 & 91 \\
\hline lender & 331 & 33 & 274 & 15 & 82 & 18 & 49 & 13 \\
\hline shareholder & 327 & 33 & 480 & 26 & 108 & 24 & 35 & 9 \\
\hline $\begin{array}{l}\text { capital } \\
\text { provider }\end{array}$ & 244 & 24 & 154 & 8 & 60 & 13 & 41 & 11 \\
\hline creditor $^{21}$ & 165 & 16 & 68 & 4 & 45 & 10 & 41 & 11 \\
\hline analyst & 46 & 5 & 335 & 18 & 10 & 2 & 129 & 35 \\
\hline manager & 156 & 16 & 605 & 33 & 32 & 7 & 68 & 18 \\
\hline $\begin{array}{l}\text { fund } \\
\text { manager }\end{array}$ & 82 & 8 & 162 & 9 & 5 & 1 & 2 & 1 \\
\hline $\begin{array}{l}\text { investment } \\
\text { manager }\end{array}$ & 13 & 1 & 111 & 6 & 0 & 0 & 6 & 2 \\
\hline $\begin{array}{l}\text { asset } \\
\text { manager }\end{array}$ & 1 & $\mathbf{0}$ & 59 & 3 & 0 & 0 & 16 & 4 \\
\hline stakeholder & 42 & 4 & 139 & 8 & 40 & 9 & 48 & 13 \\
\hline employee & 38 & 4 & 118 & 6 & 9 & 2 & 16 & 4 \\
\hline public $^{22}$ & 239 & 24 & 243 & 13 & 24 & 5 & 114 & 31 \\
\hline citizen & 4 & 0 & 1 & $\mathbf{0}$ & 0 & $\mathbf{0}$ & 5 & 1 \\
\hline
\end{tabular}

Looking at the comment letters submitted by the actual users more closely, the second and third most frequently mentioned identities of a made-up user are 'analysts' and 'public' respectively. The association with analysts is not surprising taking into account the substantial participation of 'sophisticated' users (when 'real' users get involved) in the process. What is, however, interesting is the prominence of references to 'public' among the user community

\footnotetext{
${ }^{21}$ The results include frequencies of both singular and plural forms (e.g., the frequency of 165 of the lemma 'creditor' includes 'creditors' too).

${ }^{22}$ The frequencies of the lemma 'public' do not include the phrase 'public accountant' because we wanted to see the extent to which the public at large is mentioned in the texts excluding the accounting professional titular references, that is, 'Public Accountant'.
} 
This is a pre-publication version accepted for Accounting, Organizations and Society (in press). Please refer to the published version of this article if you wish to quote from it.

that submitted comment letters. The user lobby group mentions 'public' most frequently across all constituent groups, which would suggest that they indeed identify themselves with the public or at least invoke the public the most as compared to other groups. The second lobby group that mentions 'public' most frequently is the accounting profession. This could be explained by the fact that its ethical code of practice prescribes acting in the public interest (Cooper \& Robson, 2006; Suddaby, Gendron, \& Lam, 2009) and therefore public would feature as a fixed component of their reasoning. Regulators (which comprise mainly national accounting standard-setters) mention public least frequently, which is surprising as public interest features as the objective for financial reporting at a national level across the world even if only rhetorically (Arnold, 2009). Below we provide some examples of the way in which this identity of users is invoked by the main lobbying groups:

The Institute operates under a Royal Charter, working in the public interest. Its regulation of its members, in particular its responsibilities in respect of auditors, is overseen by the Financial Reporting Council. (AP - CL70)

The Institute's Charter requires the Accounting Standards Committee to act primarily in the public interest, and our responses to consultations are therefore intended to place the general public interest first. (AP - CL95)

... we argued that the IASB has, by suggesting that present and potential capital providers be considered the primary user group for general purpose financial reporting, failed in its duty to fulfil the mandate given to it to promote global accounting standards in the public interest. (U - CL5)

Our aim is to provide the best possible regulation of these charities in order to increase charities' efficiency and effectiveness and public confidence and trust in them. (U-CL53)

Although the term 'public' occurs comparatively often in the accounting profession, most instances are repetitions of the phrase 'public interest', which is used in a general disclaimerlike manner emphasizing the responsibility of the profession to act in the interest of the public and no elaboration is provided as to how this can be achieved. The first two examples are indicative of this tendency. Comments from 'real' users show a little bit more engagement (at least in lexical terms) when it comes to arguing in favour of the public.

In summary, our study finds evidence that, by claiming to speak on behalf of users and therefore constructing their needs and wants, all constituent groups 'make up' a passive homogenous but at the same time abstract user (Young, 2006), a vague rhetorical construct rather than a tangible real stakeholder, as indicated by the patterns of transitivity (object/patient position) and frequent association of the term 'user' with vague quantifiers. The descriptors of 
This is a pre-publication version accepted for Accounting, Organizations and Society (in press). Please refer to the published version of this article if you wish to quote from it.

vagueness are linguistic mechanisms that provide for practical universalization (Bourdieu, 1987) of the made-up users, which makes them a more effective symbolic construct to justify various (potentially very different) accounting propositions. Furthermore, exploring the identity of this rhetorical figure through noun collocations of the term 'user' and other identities of potential users mentioned across data sets, one particular type of 'user' emerges as the dominant protagonist, that is, the homo economicus - a mythical consistently rational economic agent (Young, 2003, 2006; Williams \& Ravenscroft, 2015), most frequently personified as an 'investor'. These general tendencies that represent the way the doxic notion of 'user' is operationalized in the regulatory discourse seem to be similar across all constituents who we have assigned into the four lobbying categories. We find little evidence of variation and if some variation occurs, this happens mostly in the comment letters produced by actual users. The user lobby group seems, for example, to assign more agency to 'users' and makes most references to 'public' across all the groups, suggesting a broader understanding or consideration of the identity of the made-up users and their needs. At the same time, the regulators are the group that invokes users as those who they either protect (when the agency is removed from 'users') or are advised by (when agency is retained by 'users'). It has to be said, however, that overall all constituent groups, including a representation of 'real' users, do 'sign up' to the 'ruling' interpretation of the construct of users in the regulatory debates. Our findings confirm claims offered in prior research (Young, 2003, 2006; Williams \& Ravenscroft, 2015) but at the same time they deeper our understanding of how exactly the taken-for-granted notion of made-up users is deployed discursively.

\section{Conclusions and implications for future research}

Our study has shown a rich and nuanced picture of the ways in which the notion of made-up user is discursively constructed and operationalized across the four main constituent groups that shape debates in international accounting standard setting arena. Extending Bourdieu's theorization of language as a symbolic power within Firthian phraseological theory, specifically the concept of collocation, we provide empirical evidence for the existence of specific traits and characteristics attributed to made-up users as revealed though patterns of repeated language choices. The identified patterns show a consistent use of the same or similar language choices across all main constituent groups. This indicates a high hegemonic value of the 'ruling' interpretation of who the users and their needs are and is mostly grounded in the notion of passive and generic homo-economicus. The passivity is exemplified through the 
This is a pre-publication version accepted for Accounting, Organizations and Society (in press). Please refer to the published version of this article if you wish to quote from it.

grammatical objectification, while genericity is evoked through the consistent use of vague quantifiers. At the same time, our consistent comparisons have revealed some subtle differences with the constituents who we assigned to the 'real users' displaying some level of agency and diversity when invoking the construct of users.

One possible theoretical explanation of the saliency of the commonalities is that the regulatory discourse might be a product of a specific transregulatory group of comment letter writers that operates as a separate epistemic community of practice beneath the categorizations that we have assigned to the constituents. This group may shape the institutional discourse in the regulatory debates and, having captured control over the interpretation of the taken-forgranted notion of a made-up user, represents, replicates, and reinforces a discursive mode of the homo economicus hegemony in the regulatory field. When submitting a written comment on the regulatory proposals, constituents may use specialized agents (perhaps part of a respondent's organization), whose specific function is to write responses to the drafts of accounting standards released for public consultation. Therefore, our findings potentially question the significance of the constituent taxonomies applied by the extant literature that investigates lobbying activities via comment letter submissions (e.g., Tutticci et al., 1994; Jorissen et al., 2012; Pelger \& Spieß, 2017). The arbitrariness (and perhaps conventionality) of the categorization of the accounting stakeholders constitutes also one of the limitations of our study. Future research could explore the actual practices around comment letter writing by approaching representatives from different accounting constituencies to investigate how they go about preparing their responses to the official IASB regulatory proposals. This could shed some light on the institutional practices around submissions and reveal who the real producers of the formal regulatory discourse are in the (international) accounting standard-setting arena.

We believe that the constructed identity of 'user' as a generic and passive homo economicus is problematic since, without the active and meaningful role of the diverse user community in the accounting standard-setting process, how can we be sure that the process accurately captures the wide variety of users and their needs (Durocher \& Gendron, 2011)? Our findings reveal that even 'real' users who actively participate in the regulatory process (and who are notably often represented by financial analysts and investors) seem to 'sign up' largely to the dominant regulatory construction of the standardized passive homo economicus. The initial absence or rather exclusion of 'real' users that provided opportunities for the creation of the made-up users that "desire only information of the type outlined in the conceptual framework" (Young, 2006, p. 597) is perpetuated by the actual users' continuous absence and non- 
This is a pre-publication version accepted for Accounting, Organizations and Society (in press). Please refer to the published version of this article if you wish to quote from it.

engagement. Moreover, they are perceived by regulators and key constituents as 'useless' and uninterested (Pelger \& Spieß, 2017), which further reinforces their exclusion. The more 'useless' and disengaged the 'real' users are (or perceived to be) the more redundant they become, which makes it easier to 'keep them out' of the regulatory arena. It might also be argued that even the regulatory outreach activities and empirical accounting research that considers mainly investors and financial analyst as 'users' of financial statements perpetuates this situation.

Some empirical research suggests that the actual users do not use, rely on, or even trust disclosures provided in financial statements and obtain information they need in alternative ways or have learned what to pick and choose from those disclosures (Georgiou, 2017). Consequently, they might not be too concerned with the specific outcomes of the regulatory processes. Thus, we end up with the dissonance between the real world of actual users and their needs, and the self-referential regulatory realm of made-up users that guide the actions of standard setters. Thus two autonomous systems of practice are in operation, which touch each other but preserve their autonomy. We suggest that such a state of affairs is perhaps convenient for both sides. The self-referentiality of the IASB (and the key players that influence the regulatory outcomes) is mirrored by the modest real use of the resultant accounting information made by actual users of financial statements. Despite of all the recent user outreach activities, regulators and the key players in the regulatory arena might not be genuinely interested in learning what the 'real' users' needs are, as this would make the standard-setting process more complex, unpredictable or even unmanageable. In effect, the presence of made-up users facilitates the absence of real users.

Yet, the notion of a made-up user remains significant because it is essential for the construction and functioning of the accounting regulatory field. Reducing the diversity of users to the construct of a passive and generic home economicus allows for a "practical universalization" (Bourdieu, 1987, p. 845), that is, standardization and generalization in practice of the complexity of the broad universe of all potential users so that the whole system of standard setting can operate. In Bourdieu's sense, we can describe it as a "seal of universality" (Bourdieu, 1987, p. 845), which is the quintessential carrier of symbolic effectiveness. Symbolic effectiveness works here through removing any divergences from the 'ruling' view held by key players of who the users of financial statements are. Consequently, the standardised narrow view of made-up users can be easily applied to legitimise all accounting solutions under all circumstances. This practical universalization is reinforced by 
This is a pre-publication version accepted for Accounting, Organizations and Society (in press). Please refer to the published version of this article if you wish to quote from it.

the consistent use of vague quantifying expressions which imply heterogeneity and diversity (e.g. "a broad range of users", a "wide range of users"), but what they do instead is to homogenise the users to one unspecified category. It seems that a reversal is achieved in that 'broad' is deployed to mean 'narrow' and 'widening' to 'restrict'.

Given the significance of the made-up notion of users in sustaining the structures of the accounting regulatory field there are several areas that future research using a corpus-based discourse analysis could address. Since the users and their needs change over time (together with economic and political circumstances), future research could use the corpus-based approach to study data diachronically, that is, using samples produced at different times in order to examine whether the construction of made-up users and their needs change over time and in response to external factors, such as economic or political dynamics. This would be an interesting research agenda given Young's (2006) critique that the fictitious users' (made-up) decision making is assumed to be constant across periods and economic situations. Equally, the approach could be used to consider the nature of the accounting standards under investigation at a given point in time or over a number of years. This research could be conducted comparatively across key stakeholder groups in the regulatory arena. Another avenue for further enquiry is to investigate the user community in more detail to determine whether there are any differences in the construction of users' needs depending on the type of a real user providing the comment. A corpus-based approach could also be useful to explore how other taken-for-granted notions, for example, integrated thinking, sustainability, or responsible investments are discursively constructed and operationalized in accounting and business discourses across different texts and genres.

Our study has shown benefits of a multidisciplinary perspective on investigating institutional discourse in accounting. Borrowing analytical techniques from other fields of science, linguistics in particular, can provide useful insights into studying accounting as a social practice and complement and enrich the extant body of discourse analysis in accounting. As demonstrated in this study, paying more attention to recurrent language choices, as well as their lexical and structural properties and 'neighbourhoods' in large amounts of textual data, can reveal deeply ingrained and nuanced patterns that constitute dominant discourses and therefore dominant social practices in a given field. We therefore contend that insights from linguistics we utilized in our study has much to offer in furthering research within accounting as is already the case in the field of management and organizational studies (e.g., Cornelissen, 2008; O'Reilly \& Reed, 2011; Pollach, 2012; Mautner, 2016). 
This is a pre-publication version accepted for Accounting, Organizations and Society (in press). Please refer to the published version of this article if you wish to quote from it.

Yet, our analytical approach is not without its limitations. We argued earlier that a corpusbased study helps reduce some of the human biases to which qualitative discourse analysis might be prone. Nevertheless, a corpus-based approach to discourse is not entirely free from biases. Subjectivity plays a role throughout the process of corpus compilation and subsequent decisions about what to focus on and which cut-off point to use for deciding on the span for collocational analysis (four or five words to the left and to the right). At present, no firmly set standards exist. Outputs too require human interpretation as in the case of qualitative discourse analysis and these are prone to subjective judgments (Baker, 2006, p. 18). Nonetheless, the corpus-based approach allows us to identify patterns that occur consistently across the data set(s) and forms of quantification can help with over- or under-interpretation. In other words, it allows us to strike the balance between breadth and depth of the analysis. Another limitation of a corpus-based approach is that it studies texts only. While texts are important vehicles through which social agents communicate and legitimize their actions, there are also other modes of communication, for example, visual or other multimodal forms that at present cannot be explored using this methodology.

The outputs of accounting are important to companies, economies, and to society at large. The history of accounting shows that the impact and implications of accounting regulatory and governance solutions are often controversial, particularly when accounting does not work in the way anticipated or claimed (Cooper, Puxty, Robson, \& Willmott, 1994; Cooper, Everett, \& Neu, 2005; Cooper \& Neu, 2006; Arnold, 2009). The habitual use of discourse helps create, sustain, and defend demagogic arguments that preserve the status quo or potentially protect vested interests (Young, 1996, 2017; Durocher \& Gendron, 2011). This paper highlights how Bourdieu's theorizing, together with linguistic insights from the phraseological theory of meaning, complemented by the corpus-based methodology, can reveal and further explore the existence of habitual discursive practices that support the circular and very often self-referential nature of implicit systems of power. We have also shown that the close investigation of how the dominant discourse of the made-up users works in the regulatory arena generates a series of new why questions regarding the actual 'flesh and blood' users' role in accounting standard setting.

\section{References}

Alexander, D., \& Archer, S. (2003). On economic reality, representational faithfulness and the true and fair override. Accounting and Business Research, 33(1), 3-17. 
This is a pre-publication version accepted for Accounting, Organizations and Society (in press). Please refer to the published version of this article if you wish to quote from it.

Andon, P., Free, C., \& Sivabalan, P. (2014). The legitimacy of new assurance providers. Making the cap fit. Accounting, Organizations and Society, 39(2), 75-96.

Altenberg, B. (1991). Amplifier collocations in Spoken English. In S. Johansson, \& A. Stenström (Eds.), English computer corpora: Selected papers and research guide, (pp. 127-147). Berlin / New York: Mouton de Gruyter.

Arnold, P. (2009). Global financial crisis: The challenge to accounting research. Accounting, Organizations and Society, 34(6-7), 803-809.

Artstein, R., \& Poesio, M. (2008). Inter-coder agreement for computational linguistics. Computational Linguistics, 34(4), 555-596.

Bailin, A., \& Grafstein, A. (2001). The linguistic assumptions underlying readability formulae: a critique. Language \& Communication, 21(3), 285-301.

Baker, P. (2004). 'Unnatural Acts': Discourses of homosexuality within the House of Lords debates on gay male law reform. Journal of Sociolinguistics, 8(1), 88-106.

Baker, P. (2006). Using corpora in discourse analysis. London: Continuum.

Baker, P., \& McEnery, T. (2015). Introduction, In Baker, P. and McEnery, T. (Eds.) Corpora and Discourse Studies : Integrating Discourse and Corpora. (pp. 1-19) Houndmills, Basingstoke, Hampshire: Palgrave Macmillan.

Baker, P., Gabrielatos, C., Khosravinik, M., Krzyzanowski, M., McEnery, T., \& Wodak, R. (2008). A useful methodological synergy? Combining critical discourse analysis and corpus linguistics to examine discourses of refugees and asylum seekers in the UK press. Discourse and Society, 19(3), 273-306.

Bamber, M., \& McMeeking, K. (2016). An examination of international accounting standardsetting due process and the implications for legitimacy, The British Accounting Review, 48(1), 59-73.

Baudot, L. (2018). On commitment toward knowledge templates in global standard setting: The case of the FASB-IASB revenue project, Contemporary Accounting Research, $35(2), 657-695$.

Baudot, L., Roberts, R., \& Wallace, D. (2017). An examination of the US public accounting profession's public interest discourse and actions in federal policy making. Journal of Business Ethics, 142(2), 203-220.

Beattie, V. (2014). Accounting narratives and the narrative turn in accounting research: Issues, theory, methodology, methods and a research framework. The British Accounting Review, 46(2), 111-134.

Beattie, V., McInnes, B., \& Fearnley, S. (2004). A methodology for analysing and evaluating narratives in annual reports: a comprehensive descriptive profile and metrics for disclosure quality attributes. Accounting Forum, 28(3), 205-236.

Beck, A. C., Campbell, D., \& Shrives, P. J. (2010). Content analysis in environmental reporting research: Enrichment and rehearsal of the method in a British-German context. The British Accounting Review, 42(3), 207-222.

Biber, D., Johansson, S., Leech, G., Conrad, S., \& Finegan, E. (1999). The Longman grammar of spoken and written English. London: Longman. 
This is a pre-publication version accepted for Accounting, Organizations and Society (in press). Please refer to the published version of this article if you wish to quote from it.

Booth, P., \& Cocks, N. (1990). Critical research issues in accounting standard setting. Journal of Business Finance and Accounting, 17(4), 511-528.

Bourdieu, P. (1977). Outline of a theory of practice. Cambridge: Cambridge University Press.

Bourdieu, P. (1987). The Force of Law: Toward a Sociology of the Juridical Field. The Hastings Law Journal, 38(5), 814-853.

Bourdieu, P. (1989). Social space and symbolic power. Sociological Theory, 7(1), 14-25.

Bourdieu, P. (1990). The logic of practice. Cambridge: Polity Press.

Bourdieu, P. (1991). Language and symbolic power. Cambridge, UK: Polity Press.

Bourdieu, P. (1998). Practical Reason: On the Theory of Action. Standford, CA: Stanford University Press.

Bourdieu, P. (2000), Pascalian meditations. Cambridge, UK: Polity Press.

Brivot, M., \& Gendron, Y. (2011). Beyond panopticism: On the ramifications of surveillance in a contemporary professional setting. Accounting, Organizations and Society, 36(3), $135-155$.

Carruthers, B., \& Espeland, W. (1991). Accounting for rationality: Double-entry bookkeeping and the rhetoric of economic rationality. American Journal of Sociology, 97(1), 31-69

Cho, C. H., Roberts, R. W., \& Patten, D. M. (2010). The language of US corporate environmental disclosure. Accounting, Organizations and Society, 35(4), 431-443.

Chomsky, N. (1965). Aspects of the Theory of Syntax. Cambridge, Mass: M.I.T. Press.

Cohn, N. Paczynski, M., \& Kutasa, M. (2017). Not so secret agents: Event-related potentials to semantic roles in visual event comprehension. Brain and Cognition, 119, 1-9.

Cooper, D., \& Morgan, W. (2013). Meeting the evolving corporate reporting needs of government and society: Arguments for a deliberative approach to accounting rule making. Accounting and Business Research, 43(4), 418-441.

Cooper, D., \& Neu, D. (2006). Auditor and audit independence in an age of financial scandals. Advances in Public Interest Accounting, 12, 1-15.

Cooper, D., \& Robson, K. (2006). Accounting, professions and regulation: Locating the sites of professionalization. Accounting, Organizations and Society, 31(4/5), 415-444.

Cooper, D., Everett, J., \& Neu, D. (2005). Financial scandals, accounting change and the role of accounting academics: A perspective from North America. European Accounting Review, 14(2), 373-382.

Cooper, D., Puxty, T., Robson, K., \& Willmott, H. (1994). Regulating accountancy in the UK: Episodes in the changing relationship between the state and the profession. In A. Hopwood, \& P. Miller (Eds.) Accounting as social and institutional Practice. Cambridge (pp. 270-299): Cambridge University Press.

Cornaggia, K., Franzen, L., \& Simin, T. (2013). Bringing leased assets onto the balance sheet. Journal of Corporate Finance, 22, 345-360.

Cornelissen, J. (2008). Metonymy in language about organizations: A corpus-based study of company names. Journal of Management Studies, 45(1), 79-99. 
This is a pre-publication version accepted for Accounting, Organizations and Society (in press). Please refer to the published version of this article if you wish to quote from it.

Crawford, L. (2017). Exploring the emancipatory dimensions of globalisation: The struggle over IFRS8 and country-by-country reporting. Critical Perspectives on Accounting, https://doi.org/10.1016/j.cpa.2017.10.005 (in press).

D'Addeiro, L. (2011). Artifacts at the centre of routines: Performing the material turn in routines theory. Journal of Institutional Economics, 7(2), 197-230

Davies, A. (2011). A weighty subject. Accountancy, 61, December, 15-16.

Dunning, T. (1993). Accurate methods for the statistics of surprise and coincidence. Computational Linguistics, 19, 61-74.

Durocher, S., \& Gendron, Y. (2011). IFRS: On the docility of sophisticated users in preserving the ideal of comparability. European Accounting Review, 20(2), 233-262.

Durocher, S., Fortin, A., \& Cote, L. (2007). Users' participation in the accounting standardsetting process: A theory-building study. Accounting, Organizations and Society, 32(78), 29-59.

Duval, A. M., Gendron, Y., \& Roux-Dufort, C. (2015). Exhibiting nongovernmental organizations: Reifying the performance discourse through framing power. Critical Perspectives on Accounting, 29, 31-53.

Erb, C., \& Pelger, C. (2015). Twisting words? A study of the construction and reconstruction of reliability in financial reporting standard-setting. Accounting, Organizations and Society, 40(1), 13-40.

Fairclough, N. (1989). Language and power. London: Longman.

Firth, J. R. (1957). Modes of Meaning, In Papers in linguistics, 1934-1951. London, New York: Oxford University Press.

Foucault, M. (1972). The archaeology of knowledge. New York: Harper Colophon.

Gabrielatos, C., \& Baker, P. (2008). Fleeing, sneaking, flooding: A corpus analysis of discursive constructions of refugees and asylum seekers in the UK press, 1996-2005. Journal of English Linguistics, 36(1), 5-38

Georgiou, G. (2010). The IASB standard-setting process: Participation and perceptions of financial statement users. The British Accounting Review, 42(2), 103-118.

Georgiou, O. (2017). The worth of fair value accounting: Dissonance between users and standard Setters. Contemporary Accounting Research. https://doi.org/10.1111/1911$\underline{3846.12342}$ (in press)

Giner, B., \& Arce, M. (2012) Lobbying on accounting standards: Evidence from IFRS 2 on share-based payments. European Accounting Review, 21(4), 655-691,

Golsorkhi, D., Leca, B., Lounsbury, M., \& Ramirez, C. (2009). Analysing, accounting for and unmasking domination: On our role as scholars of practice, practitioners of social science and public intellectuals. Organization, 6(6), 779-97.

Gomez, M., \& Bouty, I. (2011). The emergence of an influential practice: Food for thought. Organization Studies, 32(7) 921-940. 
This is a pre-publication version accepted for Accounting, Organizations and Society (in press). Please refer to the published version of this article if you wish to quote from it.

Grundmann, R., \& Krishnamurthy, R. (2010). The discourse of climate change: A corpus based approach. Critical Approaches to Discourse Analysis Across Disciplines, 4(2), 125146.

Harding, N., \& Mckinnon, J. (1997). User involvement in the standard-setting process: A research note on the congruence of accountant and user perceptions of decision usefulness. Accounting, Organizations and Society, 22(1), 55-67.

Hazgui, M., \& Gendron, Y. (2015). Blurred roles and elusive boundaries: On contemporary forms of oversight surrounding professional work. Accounting, Auditing \& Accountability Journal, 28(8), 1234-1262.

Hines, R. (1988). Financial accounting: In communicating reality, we construct reality. Accounting Organizations and Society, 13(3), 251-261.

Hines, R. (1989). Financial accounting knowledge, conceptual framework projects and the social construction of the accounting profession. Accounting, Auditing \& Accountability Journal, 2(2), 72-92.

Hopwood, A. (1994). Some reflections on the harmonization of accounting within the EU. The European Accounting Review, 3(2), 241-253.

IASB (2007). Exposure Draft 9 Joint Arrangements. International Accounting Standards Board.

IASB (2008). Exposure Draft 10 Consolidated Financial Statements. International Accounting Standards Board.

IASB (2011a). IFRS 10 Consolidated Financial Statements. International Accounting Standards Board.

IASB (2011b). IFRS 11 Joint Arrangements. International Accounting Standards Board.

IASB (2011c). IFRS 12 Disclosure of Interests in Other Entities. International Accounting Standards Board.

IASB (2012). Agenda Consultation. Feedback from Users of Financial Statements. Agenda Paper 5B, January 2012.

IASB (2013). Preface to the International Financial Reporting Standards. International Accounting Standards Board.

IASB (2016). IFRS 16 Leases. International Accounting Standards Board.

IASB/FASB (2008). Discussion Paper Preliminary Views on Improved Conceptual Frameworks for Financial Reporting: The Reporting Entity. International Accounting Standards Board and Financial Accounting Standards Board.

IASB/FASB (2009). Discussion Paper DP/2009/1 Leases: Preliminary Views. International Accounting Standards Board and Financial Accounting Standards Board.

IASB/FASB (2010a). Exposure Draft Conceptual Framework for Financial Reporting: The Reporting Entity. International Accounting Standard Board and Financial Accounting Standards Board.

IASB/FASB (2010b). Exposure Draft ED/2010/9 Leases. International Accounting Standards Board and Financial Accounting Standards Board. 
This is a pre-publication version accepted for Accounting, Organizations and Society (in press). Please refer to the published version of this article if you wish to quote from it.

IASB/FASB (2013). Exposure Draft ED/2013/6 Leases. International Accounting Standards Board and Financial Accounting Standards Board.

Jaworska, S. (2016). Corpora and corpus linguistics approaches to studying business language. In G. Mautner, \& F. Rainer (Eds.), Handbook of business communication: Linguistic approaches (pp. 583-606). Berlin: De Gruyter.

Jaworska, S., \& Krishnamurthy, R. (2012). On the F-word: A corpus-based analysis of the media representation of feminism in British and German press discourse, 1990-2009. Discourse \& Society, 23(4), 1-31.

Jorissen, A., Lybaert, N., Orens, R., \& Van Der Tas, L. (2012). Formal participation in the IASB's due process of standard-setting: A multi-issue/multi-period analysis. European Accounting Review, 21(4), 693-729.

Joseph, C., \& Taplin, R. (2011). The measurement of sustainability disclosure: Abundance versus occurrence. Accounting Forum, 35(1), 19-31.

Kahneman, D. \& Tversky, A. (1973). On the psychology of prediction. Psychological Review, 80(4), 237-251.

Keys, D., \& Schwartz, B. (2007). "Leaky" rationality: How research on behavioral decision making challenges normative standards of rationality. Perspectives on Psychological Science 2(2), 162-180.

Kilgarriff, A., Rychlý, P., Smrz, P., \& Tugwell, D. (2004). The sketch engine. Proc EURALEX 200. Lorient, France, 105-116.

Krippendorff, K. (2004). Content analysis : An Introduction to Its Methodology, 2nd edn.

Thousand Oaks, CA: Sage.

Lagneau-Ymonet, P., \& Quack, S. (2012). What's the problem? Competing diagnoses and shifting coalitions in the reform of International Accounting Standards. In R. Mayntz, (Ed.), Crisis and Control (pp. 213-246). Frankfurt/ New York: Campus.

Li, F. (2008). Annual report readability, current earnings, and earnings persistence. Journal of Accounting and Economics, 45(2/3), 221-247.

Lupu, I., \& Sandu, R. (2017). Intertextuality in corporate narratives: a discursive analysis of a contested privatization. Accounting, Auditing \& Accountability Journal, 30(3), 534564.

Malsch, B., Gendron, Y., \& Grazzini, F. (2011). Investigating interdisciplinary translations: The influence of Pierre Bourdieu on accounting literature. Accounting, Auditing \& Accountability Journal, 24(2), 194-228.

Martin, L. (2003). What is field theory? American Journal of Sociology, 109(1), 1-49.

Masocha, W., \& Weetman, P. (2007). Rhetoric in standard setting: The case of the going concern audit. Accounting, Auditing \& Accountability Journal, 20(1), 74-100.

Mautner, G. (2016). Discourse and management: Critical perspectives through the language lens. London: Palgrave Macmillan.

McEnery, T., \& Hardie, A. (2012) Corpus linguistics. Method, theory and practice. Cambridge: Cambridge University Press. 
This is a pre-publication version accepted for Accounting, Organizations and Society (in press). Please refer to the published version of this article if you wish to quote from it.

Morgan, G. (1988). Accounting as reality construction: Towards a new epistemology for accounting. Accounting, Organizations and Society, 13(5), 477-486.

Morley, J. (2016). Internal lobbying at the IASB. Journal of Accounting and Public Policy, 35, 224-255.

Mouck, T. (2004). Institutional reality, financial reporting and the rules of the game. Accounting, Organizations and Society, 29(5/6), 525-541.

Mynatt, C., Doherty, M., \& Tweney, R. (1977). Confirmation bias in simulated research environment: An experimental study of scientific inference. Quarterly Journal of Experimental Psychology, 29(1), 85-95.

Nielsen, C., \& Madsen, M. T. (2009). Discourses of transparency in the intellectual capital reporting debate: Moving from generic reporting models to management defined information. Critical Perspectives on Accounting, 20(7), 847-854.

Nobes, C. (2014). The development of national and transnational regulation on the scope of consolidation. Accounting, Auditing \& Accountability Journal, 27(6), 995-1025.

O'Reilly, D., \& Reed, M. (2011). The grit in the oyster: Professionalism, managerialism and leaderism as discourses of UK public services modernization. Organization Studies 32(8), 1079-1101.

Pelger, C. (2016). Practices of standard-setting: An analysis of the IASB's and FASB's process of identifying the objective of financial reporting. Accounting Organizations and Society, 50(1), 51-73.

Pelger, C., \& Spieß, N. (2017). On the IASB's construction of legitimacy - The case of the agenda consultation project, Accounting and Business Research, 47(1), 64-90

Pollach, I. (2012). Taming textual data: The contribution of corpus linguistics to computeraided text analysis. Organizational Research Methods 15(2), 263-287.

Power, M. (2010). Fair value accounting, financial economics and the transformation of reliability. Accounting and Business Research, 40(3), 197-210.

Power, M. (2019). Modelling the Microfoundations of the Audit Society: Organizations and the Logic of the Audit Trail. https://doi.org/10.5465/amr.2017.0212 (in press)

Richardson, A.J., \& Eberlein, B. (2011). Legitimating transnational standard-setting: the case of the International Accounting Standards Board. Journal of Business Ethics, 98(2), $217-245$.

Richardson, J. (2007). Analysing newspapers. An approach from critical discourse analysis. New York: Palgrave Macmillan.

Robb, S., Single, L., \& Zarzeski, T. (2001). Nonfinancial disclosures across Anglo-American countries, Journal of International Accounting, Auditing and Taxation, 10(1), 71-83.

Roberts, J. (2009). No one is perfect: The limits of transparency and an ethic for 'intelligent' accountability. Accounting, Organizations and Society, 34(8), 957-970.

Robson, K. (1994). The discourse on inflation accounting. European Accounting Review, 3(2), 195-214. 
This is a pre-publication version accepted for Accounting, Organizations and Society (in press). Please refer to the published version of this article if you wish to quote from it.

Rutherford, B. (2005). Genre Analysis of Corporate Annual Report Narratives. Journal of Business Communication, 42(4), 349-378

Rychlý, P. (2008). A lexicographer-friendly association score. In P. Sojka, \& A. Horák (Eds.) Proceedings of Recent advances in Slavonic natural language processing RASLAN (pp. 6-9). Brno: Masaryk University.

Sinclair J. (1991). Corpus, Concordance, Collocation. Oxford: Oxford University Press.

Smyth, R. (2008). NVivo (Software). In Given, L. (Ed.) The SAGE Encyclopedia of Qualitative Research Methods. SAGE Publications, 563-565.

Soper, F. J., \& Dolphin, R. (1964). Readability and corporate annual reports. The Accounting Review, 39(2), 358-362.

Stenka, R., \& Taylor, P. (2010). Setting UK Standards on the concept of control: An analysis of lobbying behaviour. Accounting and Business Research, 40(2), 1-22.

Stolowy, H., Gendron, Y., Moll, J., \& Paugam, P. (2018). Building the Legitimacy of Whistleblowers: A Multi-Case Discourse Analysis. Contemporary Accounting Research. https://ssrn.com/abstract=3171837 (forthcoming)

Stubbs, M. (2001) Words and phrases. Studies in lexical semantics. London: Blackwell.

Suchman, M. (1995). Managing legitimacy, strategic and institutional approaches. Academy of Management Review, 20(3), 571-610.

Suddaby, R., Cooper, D., \& Greenwood, R. (2007). Trans-national regulation of professional services: Governance dynamics of field level organizational change. Accounting Organizations and Society, 32(4-5), 333-362.

Suddaby, R., Gendron, Y., \& Lam (2009). The organizational context of professionalism in accounting. Accounting, Organizations and Society, 34(3-4), 409-427.

Sutton, T. (1984). Lobbying of accounting standard-setting bodies in the UK and the USA: A Downsian analysis. Accounting, Organizations and Society, 9(1), 81-95.

Sydserff, R., \& Weetman, P. (2002). Developments in content analysis: a transitivity index and DICTION scores. Accounting, Auditing \& Accountability Journal, 15(4), 523-545.

Terdiman, R. (1987). An introduction to the force of law: Toward a sociology of the juridical field by Pierre Bourdieu. The Hastings Law Journal, 38(5), 803-813.

Tetlock, P. C. (2007). Giving content to investor sentiment: The role of media in the stock market. The Journal of Finance, 62(3), 1139-1168.

Thompson, G. (1994). Early double-entry bookkeeping and the rhetoric of accounting calculation. In A. Hopwood \& P. Miller (Eds.), Accounting as Social and Institutional Practice (pp. 40-61). Cambridge: Cambridge Studies in Management.

Thompson, J. (1991). An introduction to language and symbolic power by Pierre Bourdieu. Cambridge, UK: Polity Press, 1-42.

Tutticci, I., Dunstan K., \& Holmes S. (1994). Respondent lobbying in the standard-setting process: ED 4: A case study. Accounting, Auditing and Accountability Journal, 7(2), 84-104. 
This is a pre-publication version accepted for Accounting, Organizations and Society (in press). Please refer to the published version of this article if you wish to quote from it.

Vallone, R., Ross, L., \& Lepper, M. (1985). The hostile media phenomenon: Biased perception and perceptions of media bias in coverage of the "Beirut Massacre". Journal of Personality and Social Psychology, 49(3), 577-585

Van Dijk, T. A. (1995). Discourse semantics as ideology. Discourse \& Society, 6(2), 243-289.

Verfaillie, K., \& Daems, A. (1996). The priority of the agent in visual event perception: On the cognitive basis of grammatical agent-patient asymmetries. Cognitive Linguistics, 7(2), 131-148.

Warnock, K. (1992). Structure and argument in accounting standards. Accounting and Business Research, 22(86), 179-88.

Weetman, P. (2001). Controlling the standard-setting agenda: The role of FRS 3. Accounting, Auditing \& Accountability Journal, 14(1), 85-108.

Weetman, P., Davie, E., \& Collins W. (1996). Lobbying on accounting issues: Preparer/user imbalance in the case of the operating and financial review. Accounting, Auditing \& Accountability Journal, 9(1), 59-73.

Widdowson, H. 1998. The theory and practice of critical discourse analysis. Applied Linguistics 19(1), 136-151

Williams, P., \& Ravenscroft, S. (2015). Rethinking decision usefulness. Contemporary Accounting Research, 32(2), 763-788.

Willmott, H. (1990). Serving the public interest? A critical analysis of a professional claim. In D. Cooper, \& T. Hopper (Eds.), Critical accounts (pp. 315-331). London: Macmillan.

Young, J. (1994). Outlining regulatory space: Agenda items and the FASB. Accounting, Organizations and Society, 19(2), 83-109.

Young, J. (1996). Institutional thinking: The case of financial instruments. Accounting, Organizations and Society, 21(5), 487-512.

Young, J. (2003). Constructing, persuading and silencing: The rhetoric of accounting standards. Accounting, Organizations and Society, 28(6), 621-638.

Young, J. (2006). Making up users. Accounting, Organizations and Society, 31(6), 579-600.

Young, J. (2017). Reflections on 'Outlining Regulatory Space'. Critical Perspectives on Accounting, 47(1), 1-7. 